medRxiv preprint doi: https://doi.org/10.1101/2021.09.22.21263899; this version posted September 23, 2021. The copyright holder for this preprint (which was not certified by peer review) is the author/funder, who has granted medRxiv a license to display the preprint in perpetuity. This article is a US Government work. It is not subject to copyright under 17 USC 105 and is also made available for use under a CCO license.

\title{
An 8 week randomized Dietary Guidelines for Americans -based diet intervention improves the omega-3 index of healthy women
}

Christine E. Richardson ${ }^{1}$, Sridevi Krishnan ${ }^{1,2}$, Ira J. Gray ${ }^{3,4}$, Nancy L. Keim ${ }^{1,4}$, John W. Newman $1,3,4$ * $^{2}$

1 - Department of Nutrition, University of California Davis, Davis CA

2 - Department of Pediatrics, School of Medicine, University of California San Diego, San Diego CA

3 - West Coast Metabolomics Center, Genome Center, University of California Davis, Davis CA 4 - USDA-ARS Western Human Nutrition Research Center, Davis CA

Abstract - Background: The Dietary Guidelines for Americans (DGA) recommends consuming $>1.75 \mathrm{~g} / \mathrm{wk}$ of long-chain omega-3 fatty acids to reduce the risk of cardiovascular disease (CVD) through triglyceride reduction, however individual responses to treatment vary. Objective: We sought to determine if a DGA-conforming diet (DGAD) can increase the omega-3 index (OM3I), a diet-sensitive biomarker of omega-3 fatty acid status, into a health promoting range and reduce fasting triglycerides in 8 weeks. We further explored determinants of the basal OM3I and its response to treatment. Design: This is a secondary analysis of a randomized, double-blind 8wk dietary intervention of overweight/obese women fed an $8 \mathrm{~d}$ rotating DGAD $(\mathrm{n}=22)$ or typical American diet (TAD; $\mathrm{n}=20$ ) registered at www.clinicaltrials.gov as NCT02298725. The DGAD and TAD provided individuals with $16 \pm 2 \mathrm{~g} / \mathrm{wk}$ and $1.2 \pm 0.12 \mathrm{~g} / \mathrm{wk}$ of eisocapentaenoic acid (EPA) + docosahexaenoic acid (DHA), respectively. Habitual diet and body composition were determined at baseline. OM3I, fasting triglycerides, glucose and insulin were measured at 0,2 and 8wk. Results: Baseline OM3I $(5.8 \pm 1.3 ; \mathrm{n}=42)$ was positively correlated to the dietary (EPA+DHA):dietary fat ratio $(\mathrm{p}=0.006)$, negatively correlated to the android fat mass $(\mathrm{p}=0.0007)$ and was not different between diet groups. At $8 \mathrm{wk}$, while the TAD-group average OM3I was unchanged $(5.8 \pm 0.76)$, the DGAD-group OM3I increased $(7.33 \pm 1.36 ; p<0.001)$. In the DGAD-group 9 of 22 (i.e. 41\%) participants achieving an OM3I $>8 \%$. Subgroup analyses of the DGAD-group revealed that body fat content and distribution influenced the baselinedependent response to treatment. Fasting triglyceride and OM3I changes did not correlate. Conclusions: An 8wk TAD stabilized the OM3I in a healthy range, while a DGAD increased the OM3I into a health-promoting range, but did not reduce fasting triglycerides. Fat distribution and basal omega-3 status are primary factors influencing omega-3 efficacy in overweight/obese women.

*Corresponding author: John W. Newman (john.newman2@,usda.gov) 
medRxiv preprint doi: https://doi.org/10.1101/2021.09.22.21263899; this version posted September 23, 2021. The copyright holder for this preprint (which was not certified by peer review) is the author/funder, who has granted medRxiv a license to display the preprint in perpetuity. This article is a US Government work. It is not subject to copyright under 17 USC 105 and is also made available for use under a CCO license.

Abbreviations: ALA - alpha-linolenic acid; FFQs - Block Food Frequency questionnaires; CVD - cardiovascular disease; Delta-OM3I(Wk0-8) - 8wk omega 3 index change from baseline; DGA - Dietary Guidelines for Americans; GC-MS - gas chromatography-mass spectrometry; DEXA - dual-energy x-ray absorptiometry; FAME - fatty acid methyl esters; OM3I - omega-3 index; OM3I(Wk0) - baseline omega 3 index; RBC - red blood cell; SFAT - dietary saturated fat; TAD - typical American diet; TFAT - total dietary fat; TG - triglycerides 
medRxiv preprint doi: https://doi.org/10.1101/2021.09.22.21263899; this version posted September 23, 2021. The copyright holder for this preprint (which was not certified by peer review) is the author/funder, who has granted medRxiv a license to display the preprint in perpetuity. This article is a US Government work. It is not subject to copyright under 17 USC 105 and is also made available for use under a CCO license.

\section{Introduction}

Cardiovascular disease (CVD) is a leading cause of mortality, accounting for nearly 18 million deaths worldwide in 2016 (https://www.who.int/news-room/fact-

sheets/detail/cardiovascular-diseases-(cvds)). Diet is a modifiable factor that can influence CVD risk. The consumption of the long-chain omega-3 fatty acids eicosapentaenoic acid (EPA) and docosahexaenoic acid (DHA) for CVD risk reduction has received much attention [1, 2]. Various studies have demonstrated the cardioprotective properties of EPA and DHA, with proposed mechanisms including improvements in endothelial function, fasting triglycerides (TG), blood pressure, platelet aggregation, and inflammation [3-10]. Recently, a >3g/d dose of EPA + DHA was suggested as the level required to attain these protections [9]. However, studies have shown inconsistencies in response to omega-3 fatty acid intake, which can be attributed to differences in body weight, gender, age, and genetics, among others [11-13].

3 Dietary polyunsaturated fatty acids are readily incorporated into cellular phospholipids, and their incorporation into red blood cells (RBCs) combined with the average RBC life span of $\sim 115$ days provides an accessible and time-integrated measure of dietary fatty acid intake [14, 15]. The omega-3 index (OM3I), a metric that expresses the red blood cell EPA + DHA content as a percent of total fatty acids, is a validated diet-sensitive biomarker of tissues omega-3 fatty acid levels $[11,16]$. The OM3I reflects a saturable process that responds inversely to the basal status, i.e., upon supplementation, the largest change happens in individuals that start with the lowest values within that population [17]. An OM3I range of $8-12 \%$ is associated with reduced

1 CVD risk, while values $<4 \%$ suggest elevated risk $[11,18]$. Therefore, dietary modulation of the

2 OM3I by adherence to a healthful diet with high intermittent doses of omega-3 fatty acid-rich

23 foods may provide an alternative strategy to CVD risk reduction. 
medRxiv preprint doi: https://doi.org/10.1101/2021.09.22.21263899; this version posted September 23, 2021. The copyright holder for this preprint (which was not certified by peer review) is the author/funder, who has granted medRxiv a license to display the preprint in perpetuity. This article is a US Government work. It is not subject to copyright under 17 USC 105 and is also made available for use under a CCO license.

The Dietary Guidelines for Americans (DGA), first published in 1980 and currently modified on a 5y cycle, aim to minimize the risk of developing metabolic diseases such as CVD

26 by focusing on consumption of a healthy, nutrient-dense diet. Accordingly, this intervention

27 study was planned using the 2010 DGAs, which was current at the time, that recommend a diet

28 full of fruits, vegetables, whole grains, low-fat dairy products, and a reduction of sodium, solid

29 fats, and added sugars. It also suggests the consumption of $8 \mathrm{oz}$ (i.e. $225 \mathrm{~g}$ ) per week of seafood to

30 consume a daily average of $250 \mathrm{mg}$ of eicosapentaenoic acid (EPA) and docosahexaenoic acid

31 (DHA) to enhance the omega-3 fatty acid status of the population [19]. These long-chain omega-

323 fatty acids have reported anti-inflammatory and anti-hyperlipidemic properties, and increasing

33 their intake may reduce the risk of cardiometabolic disease [20]. Common interventions

34 assessing impacts on the omega-3 status have included the consumption of EPA + DHA-rich

35 supplements or increasing the consumption of cold-water fatty fish or eggs and poultry raised on

36 DHA-rich diets [21-23]. The dominant form of omega-3 fatty acids consumed in the United

37 States is the essential fatty acid alpha-linolenic acid (ALA) [24]. While increasing the

38 consumption of plant-based foods increases the intake of ALA, due to its low rate of conversion

39 to EPA and DHA, it is generally believed that EPA and DHA consumption are required to

40 meaningfully increase their levels [25]. However, the rate of ALA conversion to EPA can be

41 significant in humans [26-28], despite a high degree of variability influenced by factors including

42 both the absolute [26] and relative [29] amounts of dietary ALA and linoleic acid, exercise [30]

43 and genetic variance in the desaturases and elongases involved in the process [31]. Therefore,

44 while EPA and DHA have a strong acute effect on omega-3 status, ALA-rich diets may

45 themselves influence this outcome. To the best of our knowledge, it is not currently known how

46 following a diet reflecting the DGAs or a typical American diet (TAD) will influence the OM3I 
medRxiv preprint doi: https://doi.org/10.1101/2021.09.22.21263899; this version posted September 23, 2021. The copyright holder for this preprint (which was not certified by peer review) is the author/funder, who has granted medRxiv a license to display the preprint in perpetuity. This article is a US Government work. It is not subject to copyright under 17 USC 105 and is also made available for use under a CCO license.

47 within 8 weeks. Moreover, it is unclear if such changes in the OM3I will correlate with changes

48 in circulating TGs of normo-lipidemic to mildly hyperlipidemic individuals in the same time

49 frame.

The current report describes a secondary analysis of a clinical intervention in pre-and

51 post-menopausal women evaluating the ability of a 2010 DGA-based diet (DGAD) to

52 beneficially alter the OM3I status and/or plasma TG levels when compared to a typical American

53 diet (TAD) defined as the median intake reported by the Centers for Disease Control and

54 Prevention, National Health and Nutrition Examination Survey. We hypothesize that the DGAD

55 will increase the OM3I status and changes in the OM3I will correlate with changes in plasma TG

56 concentrations.

Subjects and Methods

59 Study design. The present study used a randomized, double-blind, 8-week dietary intervention in

60 overweight and obese pre-and postmenopausal females registered at www.clinicaltrials.gov as

61 NCT02298725 conducted between Dec 2014 and Mar 2017.A detailed description of the study

62 design has already been published $[32,33]$. All procedures were approved by the University of

63 California, Davis (UC Davis), Institutional Review Board. Briefly, volunteers were stratified by

64 menopausal status (pre- or post-) and glucose intolerance (normal compared with insulin

65 resistant), before random assignment in a 1:1 allocation ratio to the DGAD or TAD in blocks of

66 two using Microsoft Office Excel. The study statistician generated the randomization lists using

67 color to indicate treatment, and the principal dietitian assigned the colors to specific diets and

68 implemented the randomization scheme. The randomization schedules were only communicated

69 between the statistician and the dietitian, and the dietitian's assistant was aware of and had 
medRxiv preprint doi: https://doi.org/10.1101/2021.09.22.21263899; this version posted September 23, 2021. The copyright holder for this preprint (which was not certified by peer review) is the author/funder, who has granted medRxiv a license to display the preprint in perpetuity. This article is a US Government work. It is not subject to copyright under 17 USC 105 and is also made available for use under a CCO license.

access to the sequence. Both diets were designed to maintain body weight, to consist of food and

71 beverage items commonly available at grocery stores, and to have a similar appearance. The

72 TAD was based on the $50^{\text {th }}$ percentile of the NHANES's "What We Eat in America" dietary

73 survey and the DGAD was based on food-group recommendations by the 2010 DGAs. The

74 DGAD consisted of more fruits, vegetables, whole grains, and dairy products, whereas the TAD

75 consisted of more refined grains, solid fats, and added sugars. Eight-day cyclical menus were

76 used, with each day consisting of 3 meals, snacks, and beverages designed to supply adequate

77 calories for participants to maintain their body weight. Menu planning to achieve the estimated

78 experimental differences in omega-3 fatty acid were performed using fatty acid estimates of

79 commercial food products contained in the 2014 version of the Nutrition Data System for

80 Research from the University of Minnesota - Nutrition Coordinating Center

81 (http://www.ncc.umn.edu/products/). All meals were prepared by the Metabolic Kitchen and

82 Human Feeding Laboratory at the USDA - Agricultural Research Service - Western Human

83 Nutrition Research Center and volunteers picked up their meals twice weekly and returned

84 packaging so that compliance could be checked. A more detailed description of the meal

85 preparations, menus, and nutrition composition has been previously published [33]. All analyses

86 were performed in a blinded fashion.

88 Subjects. Pre- and postmenopausal females $(\mathrm{n}=44)$ aged $20-65$ years with a BMI $\left(\mathrm{kg} / \mathrm{m}^{2}\right)$ of 25 -

8939.9 were recruited for this intervention. Sample size was based on the study primary outcome

90 investigating the impact of diet quality on glucose homeostasis in women with at least one risk

91 factor for the metabolic syndrome [33].Sententary women or those with low physical activity

92 levels were recruited with inclusion criteria below the physical activity guidelines of moderate 
medRxiv preprint doi: https://doi.org/10.1101/2021.09.22.21263899; this version posted September 23, 2021. The copyright holder for this preprint (which was not certified by peer review) is the author/funder, who has granted medRxiv a license to display the preprint in perpetuity. This article is a US Government work. It is not subject to copyright under 17 USC 105 and is also made available for use under a CCO license.

93 activity of $150 \mathrm{~min} /$ week, a resting blood pressure of $\leq 140 / 90 \mathrm{mmHg}$, and if they had 1 or more

94 of the following clinical measures of glucose homeostasis or lipid metabolism: 100-126 mg/dL

95 fasting glucose; 140-199mg/dL oral glucose tolerance test 2-h glucose; Quantitative Insulin

96 Sensitivity Check Index score $<0.315$ [34]; homeostasis model assessment of insulin resistance

97 (HOMA-IR) >3.67; HbA1c between 5.7-6.5, fasting triglycerides $>150 \mathrm{mg} / \mathrm{dL}$; high density

98 lipoprotein cholesterol $<50 \mathrm{mg} / \mathrm{dL}$. Exclusion criteria included: resting blood pressure

$99>140 / 90 \mathrm{mmHg}$; hemoglobin $<11.5 \mathrm{~g} / \mathrm{dL}$; total cholesterol $>300 \mathrm{mg} / \mathrm{dL}$; low density lipoprotein

100 cholesterol $>189 \mathrm{mg} / \mathrm{dL}$; triglycerides $>400 \mathrm{mg} / \mathrm{dL}$; clinically diagnosed abnormal thyroid or liver

101 function; the presence of any metabolic disease, gastrointestinal disorders, cancer or other

102 serious chronic diseases; pregnancy or lactation; use of tobacco; use of medications for elevated

103 lipids or glucose; regular use of prescription or over-the-counter medications in the 6 mo before

104 enrolling into the study; moderate or strenuous physical activity $>30 \mathrm{~min} / \mathrm{d}$ on $\geq 5 \mathrm{~d} / \mathrm{wk}$; weight

105 change of $>5 \%$ of body weight in the $6 \mathrm{mo}$ before enrolling into the study; working "graveyard"

106 shifts or forced regular all-night wake cycles; dietary restrictions interfering with the intervention

107 foods.

108

109 Food Frequency Questionnaires: To evaluate the impact of habitual diet on the basal OM3I,

110 dietary intake estimates were assessed using Block Food Frequency questionnaires (FFQs). Each

111 participant completed an FFQ approximately 1 to 2 weeks prior to the initiation of the

112 intervention, and the responses were used to reflect habitual dietary intake.

113

114 Body Composition: To allow for the analysis of body composition impacts on basal OM3I, the

115 OM3I response to treatment, and as a compounding factor on fasting triglyceride levels, dual- 
medRxiv preprint doi: https://doi.org/10.1101/2021.09.22.21263899; this version posted September 23, 2021. The copyright holder for this preprint (which was not certified by peer review) is the author/funder, who has granted medRxiv a license to display the preprint in perpetuity. This article is a US Government work. It is not subject to copyright under 17 USC 105 and is also made available for use under a CCO license.

116 energy x-ray absorptiometry (DEXA) were performed. Once during baseline (Wk0) and once

117 during week 8 (Wk8), a whole-body DEXA scan was performed using a Hologic ${ }^{\circledR}$ Discovery ${ }^{\mathrm{TM}}$

118 QDR® Series 84994 (Hologic, Inc.). This scan provided values for total lean mass, total fat

119 mass, percent body fat, and estimates of gynoid and android fat distribution.

121 Blood collection and clinical chemistry. Fasting blood samples were collected by a licensed

122 phlebotomist, directly into EDTA containing vacutainers, mixed gently, and centrifuged at

123 1300rcf for $10 \mathrm{~min}$ at $4^{\circ} \mathrm{C}$ within $30 \mathrm{~min}$ of blood collection. After plasma and buffy coat removal,

124 RBCs from a $5 \mathrm{~mL}$ blood tube were suspended in $14 \mathrm{~mL}$ phosphate-buffered saline, gently mixed,

125 and pelleted by centrifugation as described above. The washing procedure was repeated and the

126 resulting washed RBCs were transferred to polypropylene Eppendorf tubes and stored at $-70^{\circ} \mathrm{C}$

127 until analysis.

Fatty acid analyses. To determine dietary fatty acid exposures and assess their impact on red blood cell fatty acid composition, composites of each experimental meal and red blood cell fatty

131 acids were quantified as fatty acids methyl esters (FAMEs) by gas chromatography-mass

132 spectrometry. FAMEs were quantified against authentic standards correcting for methodological

133 recoveries of $\sim 5 \mu \mathrm{mol}$ of d31-tripalmitoylglyceride (Avanti Polar Lipids, Alabaster AL) [35, 36].

134 Data quality assurance / quality control measures included sample randomization, the inclusion

135 of procedural blanks, duplication of 5\% of samples, concurrent analysis of laboratory reference

136 materials in each analytical batch, and the use of isotopically labeled extraction surrogates. Briefly, fatty acids in $\sim 50 \mathrm{mg}$ meal composites or $50 \mu \mathrm{L}$ of phosphate-buffered saline-

138 washed RBCs were extracted with 10:8:11 cylcohexane:isopropanol: 0.1M ammonium acetate in 
medRxiv preprint doi: https://doi.org/10.1101/2021.09.22.21263899; this version posted September 23, 2021. The copyright holder for this preprint (which was not certified by peer review) is the author/funder, who has granted medRxiv a license to display the preprint in perpetuity. This article is a US Government work. It is not subject to copyright under 17 USC 105 and is also made available for use under a CCO license.

the presence of deuterated analytical surrogates [37]. Meal composite and RBC extracted lipid residues were reconstituted in either $1 \mathrm{~mL}$ or $200 \mu \mathrm{L}$ of $1: 1$ methanol/toluene $(\mathrm{v} / \mathrm{v})$, respectively,

141 and stored at $-20^{\circ} \mathrm{C}$ until derivatization. Isolated lipids were transformed into FAMEs by

142 sequential incubation with methanolic sodium hydroxide and methanolic hydrochloric acid.

143 Specifically, $25 \mu \mathrm{L}$ of meal composite extract or $20 \mu \mathrm{L}$ of RBC extracts were further diluted

144 with $20 \mu \mathrm{L}$ of $1: 1$ toluene/methanol (v/v), enriched with $20 \mu \mathrm{L}$ of $60 \mu \mathrm{M} 10 Z$-pentadecenoic acid

145 in methanol, diluted with $140 \mu \mathrm{L}$ methanol, mixed with $100 \mu \mathrm{L}$ of $0.5 \mathrm{M}$ sodium methoxide,

146 headspace flushed with nitrogen and incubated at $60^{\circ} \mathrm{C}$ for $1 \mathrm{~h}$. Samples were cooled 5 min

147 before addition of $100 \mu \mathrm{L}$ of $3 \mathrm{~N}$ methanolic hydrochloric acid, and returned to $60{ }^{\circ} \mathrm{C}$ for $30 \mathrm{~min}$.

148 Reaction mixtures were then neutralized with $400 \mu \mathrm{L}$ potassium carbonate, mixed with $400 \mu \mathrm{L}$

149 saturated sodium chloride, and back extracted with $400 \mu \mathrm{L}$ hexane.

FAMEs were separated on a $30 \mathrm{~m} \times 0.25 \mathrm{~mm}, 0.25 \mu \mathrm{m}$ DB-225ms on $7890 \mathrm{~B}$ gas

151 chromatograph interfaced with a 5977B mass selective detector (Agilent Technologies) and

152 quantified against 6- to 8-point calibration curves. Calibrants and internal standards were

153 purchased from NuchekPrep (Elysian, MN) or Sigma-Aldrich (St. Louis, MO). Data were

154 acquired and processed with MassHunter v. 3.2. Results were corrected for

155 d31-tripalmitoylglyceride recoveries which were $47 \pm 15 \%$ and $49 \pm 12 \%$ for meal composites

156 and RBCs, respectively, with derivatization efficiencies of $\sim 50 \%$. Replicate precision indicated

157 precision of $\sim 15 \%$ for RBC FAMEs above the detection limits and recoveries did not differ by

158 treatment group or time.

Statistics: Data normality was assessed using Shapiro-Wilkes tests and Q-Q plots of raw, log,

161 and Johnson transformed data. Johnson transformations were the most robust and used for 
medRxiv preprint doi: https://doi.org/10.1101/2021.09.22.21263899; this version posted September 23, 2021. The copyright holder for this preprint (which was not certified by peer review) is the author/funder, who has granted medRxiv a license to display the preprint in perpetuity. This article is a US Government work. It is not subject to copyright under 17 USC 105 and is also made available for use under a CCO license.

162

163

164

165

166

167

168

169

170

171

172

173

174

175

analyses unless indicated. Mean differences were assessed with Student's t-test. Colinear dietary and body composition factors were clustered using an implementation of the VARCLUS algorithm. The influence of physiological parameters and habitual diet on the baseline OM3I were evaluated using linear mixed models alone and together. The minimum set of strong OM3I predictors were generated by stepwise linear regressions with the Bayesian information criterion (BIC) minimization as the stopping function. The influence of diet group and study week on RBC fatty acid composition was assessed using linear mixed models with participant as a random effect with group and week as main effects, followed by adjusted multiple comparison tests (Least Square Means Tukey HSD) if main or interaction effects were identified. Pearson's correlations were used to assess correlations in change (wk8-wk0) after adjustement for baseline values. Participants in the DGAD group with the lowest and highest OM3I change were segregated into two magnitude response subgroups using hierarchical cluster analyses of the 0wk to 8 wk change in the OM3I (Delta-OM3Iwk0-8). Participants were also segregated into OM3I rate of change response subgroups by diet. To this end, $\mathrm{K}$ means clustering, the fold-change in the Wk0 to $\mathrm{Wk} 2 \mathrm{OM} 3 \mathrm{I}$ and the $8 \mathrm{wk}$ rate of change in the OM3I were used together. All statistical analyses were performed in JMP Pro v 15.1 (SAS Institute, Cary, NC).

\section{Results}

Participant numbers and characteristics: A complete diagram of the enrollment, allocation, follow-up and analysis is provided in Figure 1. Of the 52 participants enrolled, 44 completed the intervention without adverse effects. Summarized baseline characteristics of the participants included in the primary analysis are shown in Table 1, with participant level data provided in

Supplemental Table S1. However, RBC fatty acid results were unavailable for one baseline and 
medRxiv preprint doi: https://doi.org/10.1101/2021.09.22.21263899; this version posted September 23, 2021. The copyright holder for this preprint (which was not certified by peer review) is the author/funder, who has granted medRxiv a license to display the preprint in perpetuity. This article is a US Government work. It is not subject to copyright under 17 USC 105 and is also made available for use under a CCO license.

185

186

187

188

189

190

191

192

193

194

195

one terminal blood draw from 2 individuals in the TAD group due to poor analytical performance $(\mathrm{n}=2 / 132$; i.e. $1.5 \%)$. Therefore, analyses for the primary outcome of intervention change in OM3I and secondary outcomes investigating the influence of body composition on the change in OM3I and the interaction between OM3I change and fasting triglyceridemia were performed with $n=22$ for the DGAD and $n=20$ for the TAD groups. In the DGAD group, a single individual showed inconsistancies between their pre-screening and baseline fasting triglyceride levels, and analyses were performed with and without this subject.

Diet and red blood cell fatty acids profiles: The average fatty acid composition of both diet plans are shown in Table 2, while the corresponding average gram amounts delivered in the 8-day meal rotations are shown in Table 3. The individual participant daily intake of each fatty acid is provided in Supplemental Table S2. These analyses confirmed that the aggregate TAD contained higher saturated fatty acids (SFA) and monounsaturated fatty acids (MUFA) compared to the DGAD (Figure 2A). The TAD also had lower omega-3 polyunsaturated fatty acids (n3PUFAs), with the relative abundance of n6-PUFAs being equivalent between the two diets. The average daily intake of EPA + DHA for the 8-day menu cycle was $0.18 \pm 0.02$ and $2.24 \pm 0.33$ $\mathrm{g} / \mathrm{d}$ for the TAD and DGAD, respectively. However, as can be seen in Figure $2 \mathbf{B}$ in the DGAD meal plan, long-chain n3-PUFAs were provided solely in three independent meals on Day 1, Day 5, and Day 7 with the EPA + DHA levels of $3.0 \pm 0.42,2.5 \pm 0.37$, and $12 \pm 1.7 \mathrm{~g} / \mathrm{d}$, or approximately $34 \pm 3,29 \pm 3$ and $133 \pm 11 \mathrm{mg} / \mathrm{kg}$ body $\mathrm{wt}$, respectively in menu day composites. Moreover, both meal plans contained a substantial amount of ALA. The foods providing the majority of omega-3 fatty acids are described in Table 4, and in more detail in Supplemental 
medRxiv preprint doi: https://doi.org/10.1101/2021.09.22.21263899; this version posted September 23, 2021. The copyright holder for this preprint (which was not certified by peer review) is the author/funder, who has granted medRxiv a license to display the preprint in perpetuity. This article is a US Government work. It is not subject to copyright under 17 USC 105 and is also made available for use under a CCO license.

Table 3. The diet group average RBC fatty acid composition at baseline and after 2 and 8 wk of dietary intervention are shown in Table 5.

Habitual diet and physiological correlates with baseline OM3I: Combined analyses of FFQ in

211 Supplemental Table S4 and baseline body composition data in Supplemental Table S1 using

212 the entire set of completeing subjects $(n=44)$ identified the estimated dietary EPA +

213 DHA:dietary saturated fat ratio (i.e. (EPA+DHA):SFA) and android fat mass as the strongest

214 predictors of baseline OM3I (OM3I $(\mathrm{Wk} 0))$. Variable clustering of FFQ data showed the OM3I to

215 be contained in a cluster with the dietary EPA + DHA, the (EPA+DHA):dietary saturated fat

216 (SFAT) ratio, the (EPA+DHA):total dietary fat (TFAT) ratio, and the MUFA:TFAT ratio. Of

217 these, the (EPA+DHA):SFAT ratio and (EPA+DHA):TFAT ratio were the most strongly

218 correlated with the OM3I $(\mathrm{Wk} 0)(\mathrm{p}<0.01)$ and FFQ estimated EPA + DHA intake was the weakest

$219(\mathrm{p}=0.06)$. Exploring the baseline OM3I correlations with body composition data showed android

220 fat to be negatively correlated and the single best body composition predictor of this status

221 marker $\left(\mathrm{r}^{2}=0.25, \mathrm{p}=0.0007\right)$. Combining dietary and body composition factors into a stepwise

222 linear regression analysis yielded an improved model explaining $43 \%$ of the variance in the

223 baseline OM3I $\left(r^{2}=0.43, p<0.0001\right)$, which included android fat mass $(p=0.00012)$ and the

224 (EPA+DHA):SFA ratio $(\mathrm{p}=0.0018)$ or $($ EPA+DHA):TFAT ratio (Supplemental Figure 1). The

225 android fat mass and (EPA+DHA):SFA or $(\mathrm{EPA}+\mathrm{DHA})$ :TFAT were not correlated $(\mathrm{p}=0.9)$.

227 Intervention diet impact on RBC lipids and the OM3I: The fatty acid composition of RBCs was

228 differentially altered by intervention diets. While no changes in SFAs or MUFAs were observed,

229 a variety of changes in the PUFAs were noted. In terms of the amount of lipid per mg of RBC, 
medRxiv preprint doi: https://doi.org/10.1101/2021.09.22.21263899; this version posted September 23, 2021. The copyright holder for this preprint (which was not certified by peer review) is the author/funder, who has granted medRxiv a license to display the preprint in perpetuity. This article is a US Government work. It is not subject to copyright under 17 USC 105 and is also made available for use under a CCO license.

DHA was increased by the DGAD $(p=0.041)$ but not TAD $(p=0.3)$. Concentrations of EPA were marginally increased $(\mathrm{p}=0.08)$ and decreased $(\mathrm{p}=0.1)$ by the DGAD and TAD,

232 respectively. When expressed as a mole percent composition, the DGAD group showed increases

233 in EPA and DHA ( $<<0.0001)$, and decreases in C22:5n6 (DPA; $p=0.012)$, while the TAD

234 showed a decreased EPA composition $(\mathrm{p}=0.013)$, reflected in a 20\% reduction in the EPA/DHA

235 relative abundance $(\mathrm{p}=0.0019)$. The level of ALA in RBCs was near the analytical detection

236 limit in the assay as applied, and the resulting data were not available for analysis. This is in

237 agreement with reports of RBC ALA content of $\sim 0.1 \mathrm{~mol} \%$ [38].

238 While baseline OM3I of $\sim 5.6$ did not differ by group (Table1), at study completion, the

239 DGAD-group OM3I increased to $7.33 \pm 1.36(\mathrm{p}<0.001)$, while the the TAD-group OM3I was

240 unchanged at $5.8 \pm 0.76(\mathrm{p}=0.6)$. As previously reported $[17,21]$, the baseline omega-3 status

241 influenced the individual response to the intervention. As seen in Figure 3, after 2 weeks of

242 feeding changes in the OM3I were driven by baseline associated interactions in both groups.

243 However, after 8 weeks of feeding, a significant elevation in the OM3I is observed in the

244 DGAD-group, with 21 of 22 (i.e. 95\%) participants demonstrating an increase, as opposed to

245 only $30 \%$ of the TAD-group.

247 OM3I response subgroup analysis: Despite equivalent dietary omega-3 intake in the DGAD,

248 substantial variability in the response was observed that were not fully explained by the basal

249 OM3I status. A cluster analysis of the baseline adjusted 8wk change in the OM3I segregated the

250 DGAD-group into high and low responsive clusters, while the TAD-group remained as a single

251 group (Figure 3A). A linear mixed model of the DGAD 8wk change in OM3I

252 (Delta-OM3 $\left.\mathrm{I}_{(\mathrm{Wk} 0-8)}\right)$ using $\mathrm{OM} 3 \mathrm{I}_{(\mathrm{Wk} 0)}$ and the OM3I response group, revealed a significant 
medRxiv preprint doi: https://doi.org/10.1101/2021.09.22.21263899; this version posted September 23, 2021. The copyright holder for this preprint (which was not certified by peer review) is the author/funder, who has granted medRxiv a license to display the preprint in perpetuity. This article is a US Government work. It is not subject to copyright under 17 USC 105 and is also made available for use under a CCO license. interaction between $\mathrm{OM} 3 \mathrm{I}_{(\mathrm{Wk} 0)}$ and the $8 \mathrm{wk}$ Delta-OM3 $\mathrm{I}_{(\mathrm{Wk} 0-8)}(\mathrm{p}=0.049)$, with the OM3 $\mathrm{I}_{(\mathrm{Wk} 0)}$

254 having a weaker influence in the low reponders. The low responsive group also showed evidence 255 of reduced insulin sensitivity as measured by HOMA-IR $(\mathrm{p}=0.045)$, with 8 of 9 low responsive 256 individuals with HOMA-IR scores $>2.1$, as opposed to only 6 of 13 high responsive individuals.

257 A K-means clustering of the rate of change in the OM3I between 0 and 8 wk and the log of the

258 fold-change between wk 0 and 2, identified 3 unique clusters for both the TAD and DGAD

259 groups as shown in Figure 3B. In the DGAD-group, the OM3I increased $1.0 \pm 0.5,2.6 \pm 0.5$,

260 and $3.4 \pm 0.8$ in clusters 1,2 , and 3, respectively. In the TAD-group, the average OM3I increased 261 by $0.8 \pm 0.3$ in cluster 1 , remained unchanged (i.e. $-0.1 \pm 0.3$ ) in cluster 2 , and decreased by $1.4 \pm$ 2620.6 in cluster 3.

Determinants of OM3I change: It has previously been reported that baseline OM3I, body mass, 265 age, sex, and physical activity are strong determinants of the OM3I response to supplementation 266 [12]. Considering the TAD- and DGAD-groups together $(\mathrm{n}=42)$, the baseline OM3I alone 267 explained 34\% of the OM3I response (Supplemental Figure 2). However as intervention 268 exposures were significantly different, an analysis by diet was performed. In the TAD group $26974 \%$ of the variance in the Delta-OM3 $\mathrm{I}_{(\mathrm{Wk} 0-8)}$ was explained by negative correlations with the 270 baseline OM3I alone $(\mathrm{p}<0.0001)$. In the DGA group only $30 \%$ of the variance was explained by 271 the OM3 $\mathrm{I}_{(\mathrm{Wk} 0)}$. Models including $\mathrm{OM} 3 \mathrm{I}_{(\mathrm{Wk} 0)}$ and the average EPA + DHA daily intake were 272 improved $\left(r^{2}=0.56, \operatorname{RMSE}=0.16, \mathrm{p}=0.0004\right)$, however, the Delta-OM3I(wk0-8) showed a 273 counterintuitive negative correlation with intake (i.e. adjusting for basal status, as dose increased 274 change decreased). A stepwise linear regression built from DEXA-based body composition, BMI 275 and age data accounted for $70 \%$ of the variance in the DGAD Delta-OM3I(Wk0-8). This false 
medRxiv preprint doi: https://doi.org/10.1101/2021.09.22.21263899; this version posted September 23, 2021. The copyright holder for this preprint (which was not certified by peer review) is the author/funder, who has granted medRxiv a license to display the preprint in perpetuity. This article is a US Government work. It is not subject to copyright under 17 USC 105 and is also made available for use under a CCO license.

276 discovery rate adjusted standard least squares regression model $\left(r^{2}=0.70, \mathrm{RMSE}=0.12\right.$;

$277 \mathrm{p}=0.002)$ included negative associations with the $\mathrm{OM} 3 \mathrm{I}_{(\mathrm{Wk} 0)}\left(\mathrm{p}_{\mathrm{adj}}=0.027\right)$, trunk $\%$ fat

278 ( $\left.\mathrm{p}_{\mathrm{adj}}=0.012\right)$, lean body mass $\left(\mathrm{p}_{\mathrm{adj}}=0.013\right)$ and positive associations with android fat mass

$279 \quad\left(p_{a d j}=0.027\right)$ and BMI $\left(p_{a d j}=0.033\right)$. As seen in Figure 4, the omega-3 fatty acid and body

280 variables condense into four correlated variable clusters. Of these factors, android fat mass is

281 positively correlated with lean body mass, BMI and trunk \% fat ( $p<0.001)$, along with the

282 average EPA+DHA daily intake. Notably, multidimensional outliers in highly correlated

283 independent variables were not observed. Exploring model factor interactions revealed

$284 \mathrm{OM}_{(\mathrm{Wk} 0)}$ interactions with android fat mass $(\mathrm{p}=0.014)$, lean mass $(\mathrm{p}=0.020)$ and BMI $(\mathrm{p}$

$285=0.025)$. Modeling the dose dependent change (i.e. $[$ Delta-OM3I $($ wk0-8) $/(\mathrm{EPA}+\mathrm{DHA})]$ and

286 including the $\mathrm{OM} 3 \mathrm{I}_{(\mathrm{Wk} 0)}$ by android fat interaction improved the model performance $\left(\mathrm{r}^{2}=0.85\right.$;

$287 \mathrm{p}<0.0001, \mathrm{RMSE}=0.011$; Supplemental Figure 3). A boosted tree analysis of the

288 Delta-OM3I $\mathrm{I}_{(\mathrm{Wk} 0-8)}$, also showed the OM3 $\mathrm{I}_{(\mathrm{Wk})}$, along with \% body fat, android \% fat, and the

289 android:gynoid fat ratio as important explanatory variables (data not shown). These analyses

290 suggest that after adjusting for the basal OM3I status, the omega-3 fatty acid response to dietary

291 EPA+DHA intake is lower as body size increases, but higher as android fat deposition increases.

293 Triglyceride response to OM3I changes: Omega 3 fatty acid intake has been reported to lower

294 circulating triglycerides. The current data set was evaluated for evidence of triglyceride

295 interactions with OM3I status. Changes in triglycerides themselves were inversely related to

296 their baseline levels, and evenly distributed between increases and decreases regardless of the

297 diet intervention group, suggesting a substantial regression to the mean effect with respect to the

298 measured changes in fasting triglycerides (data not shown). Fasting triglyceride levels were not 
medRxiv preprint doi: https://doi.org/10.1101/2021.09.22.21263899; this version posted September 23, 2021. The copyright holder for this preprint (which was not certified by peer review) is the author/funder, who has granted medRxiv a license to display the preprint in perpetuity. This article is a US Government work. It is not subject to copyright under 17 USC 105 and is also made available

directly correlated with the OM3I. In the DGAD-group, changes in the TGs, adjusted for baseline TGs, were positively correlated with changes in the OM3I, adjusted for baseline OM3I

$301\left(\mathrm{r}^{2}=0.27, \mathrm{p}=0.007\right)$. However, removal of a single fasting TG measure, a statistical outlier at

302 baseline in poor agreement with its study pre-screening TG concentration, reduced the strength

303 of this correlation $\left(\mathrm{r}^{2}=0.16, \mathrm{p}=0.08\right)$, although it remained stronger than that seen in the TAD-

304 group $\left(\mathrm{r}^{2}=0.02, \mathrm{p}=0.6\right)$. Analysis of DGAD OM3I response subgroups also showed no

305 association between the OM3I and fasting TGs.

\section{Discussion}

Increasing long-chain omega-3 fatty acid consumption is associated with reductions in

309 lipidomic cardiovascular disease risk factors [39]. The omega-3 index, defined as the sum of the

310 EPA and DHA mole percent relative to the total fatty acid content in RBCs is an established and

311 valuable omega-3 fatty acid status marker $[11,16,18]$. An OM3I between 8-12\% appears

312 protective, while a value $<4 \%$ is associated with increased CVD risk $[11,18]$. The present study

313 was established to determine if a diet based on the 2010 DGA can beneficially alter the OM3I

314 and/or blood TG concentrations when compared to a TAD, in pre-and postmenopausal women,

315 within 8 wks. A secondary analysis was performed to evaluate the influence of body composition

316 factors on the responsiveness of the OM3I to dietary omega-3 fatty acid intake.

It has been established that the baseline OM3I is negatively associated with the OM3I

318 response to omega-3 fatty acid intake, and various factors have been reported to influence this

319 status marker. For instance, FFQ-based estimates of the omega-3 fatty acid intake correlate with

320 the OM3I, and an increase in weekly additional servings of fish has been associated with a 6-

$321 \quad 13 \%$ increase in the OM3I [40-43]. Fasting triglyceride levels, age, a history of high cholesterol, 
medRxiv preprint doi: https://doi.org/10.1101/2021.09.22.21263899; this version posted September 23, 2021. The copyright holder for this preprint (which was not certified by peer review) is the author/funder, who has granted medRxiv a license to display the preprint in perpetuity. This article is a US Government work. It is not subject to copyright under 17 USC 105 and is also made available for use under a CCO license.

322

323

324

325

and smoking have also been reported to influence the OM3I [21-23, 43]. In the current study, the Block FFQ estimated EPA + DHA intake was poorly correlated with the basal OM3I unless expressed as a percentage of the total dietary fat, or its relative abundance with the saturated fat intake. Exploring associations between body composition and the OM3I, android fat mass was found to have a strong negative association with the baseline OM3I, which was independent of the dietary factors. Contradicting this finding, in a previous study of older women, a high dietary omega-3/omega-6 ratio was associated with higher android fat [44]. That study also found that a high dietary SFA/PUFA ratio was positively associated with android fat, a relationship that was weakly observed in the current data $(\mathrm{p}=0.1)$. Regardless, elevations in android fat deposition are reportedly associated with elevated plasma triglycerides, endothelial dysfunction, type 2 diabetes, and fatty liver disease [45-48], all conditions beneficially affected by high omega-3 fatty acid intake.

As demonstrated by the diet composition analysis, following the DGA recommendations significantly alters the dietary fat balance relative to a TAD, with elevations in n3-PUFAs and reductions in saturated fats. The DGAD provided $\sim 2.25 \mathrm{~g} / \mathrm{d}$ of EPA+DHA primarily in 3 meals of the 8-day rotating menu. Meals on these days included servings of $80 \mathrm{~g}$ of salmon or albacore tuna in multiple forms including seafood pasta, a corn and salmon chowder, a salmon dinner, and a seafood salad. In contrast, the TAD provided $\sim 0.25 \mathrm{~g} / \mathrm{d}$ of EPA+DHA. A more detailed description of the meals and there composition has been previously reported [33]. Ultimately, in this sample of overweight/obese women with a mean basal OM3I of $\sim 5.6 \%, 8$ weeks of the DGAD increased the OM3I by $1.7 \pm 1.1 \%$, while the TAD only reduced it by $-0.15 \pm 0.86 \%$, with a final OM3I of $7.4 \pm 1.35 \%$ and $5.8 \pm 0.72 \%$, respectively. While most individuals on the 
medRxiv preprint doi: https://doi.org/10.1101/2021.09.22.21263899; this version posted September 23, 2021. The copyright holder for this preprint (which was not certified by peer review) is the author/funder, who has granted medRxiv a license to display the preprint in perpetuity. This article is a US Government work. It is not subject to copyright under 17 USC 105 and is also made available for use under a CCO license.

unchanged, and 7 participants had $2.3-4.5 \%$ change in the OM3I, with 9 exceeding the recommended $8 \%$ OM3I by the end of the intervention. Therefore, it is possible to achieve a

347 putatively beneficial OM3I status in 8 weeks by adhering to DGAD recommendations with

348 significant EPA and DHA sources in only 3 meals per week. However, there is significant

349 interindividual variability in response, and rates of improvement slow as the OM3I increases,

350 consistent with previous findings [21,31]. In mixed models adjusting for the basal OM3I effect,

351 changes in the OM3I were lower as the percent trunk fat and lean body mass increased, but

352 higher as absolute android fat mass and BMI increased. Therefore, it appears that in women with

353 increased abdominal and overall adiposity the omega-3 intervention efficacy was enhanced after

354 adjusting for basal status and body size and android adiposity. However, it is also important to

355 note that women with a low OM3I intervention response also had reduced insulin sensitivity.

356 Considering that men with a higher OM3I were found to have higher insulin sensitivity [49],

357 these findings bring into question the cause-effect relationship between these factors. In contrast, 358 after the 8wk TAD intervention, the average OM3I of individuals either increased or decreased

359 toward an average OM3I of $\sim 5.8 \%$, again with some variability influence primarily by the basal

360 omega-3 fatty acid status. It is unclear if this maintenance of a modest OM3I was due to the low

361 level of EPA+DHA in the diet, or associated with ALA-dependent biosynthesis of EPA. Had this

362 change been purely associated with ALA conversion, an increase in EPA relative to DHA in the

363 TAD group might be expected [26-28]. However, the EPA:DHA ratio was actually reduced in

364 the TAD group at $8 \mathrm{wks}$, suggesting that dietary DHA and/or it biosynthesis in this diet group

365 were sufficient to maintain the OM3I in a neutral range with respect to cardiovascular disease 366 risk. 
medRxiv preprint doi: https://doi.org/10.1101/2021.09.22.21263899; this version posted September 23, 2021. The copyright holder for this preprint (which was not certified by peer review) is the author/funder, who has granted medRxiv a license to display the preprint in perpetuity. This article is a US Government work. It is not subject to copyright under 17 USC 105 and is also made available for use under a CCO license.

Dietary long chain omega-3 fatty acids can have strong hypolipidemic effects in both normal and hyperlipidemic individuals, with these lipid-lowering effects being both dose and time-dependent $[9,39,50]$. For instance, in an $8 \mathrm{wk}$ intervention comparing $2 \mathrm{~g} / \mathrm{d}$ of daily

370 supplements and 2 meals/wk of $250 \mathrm{~g}$ of trout, both treatments reduced TGs in hyperlipidemic 371 participants [22]. In another effort, $0.85 \mathrm{~g} / \mathrm{d}$ and $3.4 \mathrm{~g} / \mathrm{d}$ doses of EPA+DHA were compared in a

372 population with a baseline OM3I of $4.46 \pm 1.13 \%$. After 8 wks of treatment, the OM3I increased

373 to $6.49 \pm 0.21 \%$ and $8.79 \pm 0.21 \%$, for the low and high doses, respectively. However, only the

374 high dose resulted in TG lowering in the moderately hypertriglyceridemic cohort. Similarly, a

375 weak non-linear association between an increase in the OM3I and a decrease in fasting TG levels

376 was reported in dyslipidemic patients receiving $1.67 \mathrm{~g} / \mathrm{d}$ of EPA+DHA as fish oil capsules for

$3776 \mathrm{mo}$, with individuals having a change in the OM3I of $>4 \%$ showing the greatest TG reduction

378 [51]. In the present study of women with a basal OM3I of $5.6 \pm 1.3 \%$ and normal to mild

379 hypertriglyceridemia, only weak associations between increasing OM3I and reduced fasting TGs

380 were observed at $8 \mathrm{wk}$ in the DGAD group after outlier removal. Therefore, it cannot be

381 concluded from the current data that habitual consumption of a DGAD with elevated ALA and

382 intermittent exposure to substantial dietary EPA + DHA would reduce fasting TG in subjects if

383 maintained for a longer duration.

\section{Limitations}

386 While foods were purchased in lots to minimize variance in nutritional exposures, measured fatty 387 acids in meal composites were generated at a single time point during the course of the study and 388 the exact dietary exposures may differ from the measured composite meals. Thus omega-3 intake 389 could have varied between participants over the course of the study. The current study has a 
medRxiv preprint doi: https://doi.org/10.1101/2021.09.22.21263899; this version posted September 23, 2021. The copyright holder for this preprint (which was not certified by peer review) is the author/funder, who has granted medRxiv a license to display the preprint in perpetuity. This article is a US Government work. It is not subject to copyright under 17 USC 105 and is also made available for use under a CCO license.

390 relatively small sample size and includes individuals with a range of normal to mild fasting

391 triglyceridemia, limiting the power to detect hypotriglyceridemic effects. This fact is exacerbated

392 in the reported subgroup analysis. Moreover, genetic factors influencing both long chain omega-

3933 fatty acid biosynthesis and triglyceridemic responsiveness were not evaluated.

\section{Conclusion}

Adherence to a DGAD with $\sim 16 \mathrm{~g}$ of EPA+DHA provided in 3 meals/wk for 8 wks improves the

397 OM3I status in pre- and post-menopausal women with a basal OM3I of $5.6 \pm 1.3 \%$, while an

398 ALA-rich TAD providing $1.4 \mathrm{~g} /$ wk of EPA+DHA maintained an OM3I of $\sim 6 \%$, which is in the

399 neutral range with respect to CVD risk. While a cardioprotective OM3I of $>8 \%$ was achieved in

$40040 \%$ of participants, no concurrent decreases in fasting TGs were observed in the current

401 timeframe. Notably in women with greater abdominal and overall adiposity the omega-3

402 intervention efficacy was higher after adjusting for basal omega-3 fatty acid status and body size.

\section{Acknowledgements}

405 This study was supported by the National Dairy Council, Campbell Soup Co., and USDA-ARS

406 Projects 2032-51530-022-00D, 2032-51530-025-00D and 6026-51000-010-05S. The USDA is

407 an equal opportunity provider and employer. The National Dairy Council and Campbell Soup

408 Company did not participate in the final design, implementation, analysis, or interpretation of the

409 data from this study. Campbell Soup provided some bulk foods and associated nutrient

410 information. None of the authors had a conflict of interest to report. We thank our colleagues

411 Sean H. Adams, Lindsay H. Allen, Kevin D. Laugero, and Charles B. Stephenson for their

412 efforts in the study design and execution of the larger study in which the current experiments 
medRxiv preprint doi: https://doi.org/10.1101/2021.09.22.21263899; this version posted September 23, 2021. The copyright holder for this preprint (which was not certified by peer review) is the author/funder, who has granted medRxiv a license to display the preprint in perpetuity. This article is a US Government work. It is not subject to copyright under 17 USC 105 and is also made available for use under a CCO license.

413 were nested; Dustin Burnett for menu design and production management; Leslie Woodhouse for

414 managing the generation of clinical data; Janet Peerson for guidance and review of statistical

415 analyses. The authors' responsibilities were as follows - JWN and NLK: conceived and

416 developed the research plan; JWN, SK, IJG, and NLK: conducted the research; JWN and IJG:

417 analyzed the data and performed the statistical analysis; CER, JWN: wrote the primary

418 manuscript; SK and NLK: provided significant editorial input of manuscript; all authors: have

419 primary responsibility for final content and read and approved the final manuscript. 
medRxiv preprint doi: https://doi.org/10.1101/2021.09.22.21263899; this version posted September 23, 2021. The copyright holder for this preprint (which was not certified by peer review) is the author/funder, who has granted medRxiv a license to display the preprint in perpetuity. This article is a US Government work. It is not subject to copyright under 17 USC 105 and is also made available for use under a CCO license.

Table 1: Study cohort baseline clinical and body composition characteristics ${ }^{1}$

\begin{tabular}{clcc}
\hline Variables & Units & TAD & DGAD \\
\hline $\mathrm{n}$ & & 20 & 22 \\
Age & $\mathrm{y}$ & $48.0 \pm 10.0$ & $50.7 \pm 12.6$ \\
OM3I & $\%$ & $5.98 \pm 1.35$ & $5.63 \pm 1.27$ \\
Fasting TGs & $\mathrm{mg} / \mathrm{dL}$ & $111 \pm 49$ & $143 \pm 101$ \\
HOMA-IR & & $3.77 \pm 2.75$ & $3.22 \pm 2.43$ \\
BMI & $\mathrm{kg} / \mathrm{m}^{2}$ & $33.0 \pm 3.68$ & $32.0 \pm 4.0$ \\
Body Weight $^{2}$ & $\mathrm{~kg}$ & $88.5 \pm 13.8$ & $88.6 \pm 15.6$ \\
Total MassDEXA $^{2}$ & $\mathrm{~kg}$ & $87.0 \pm 13.7$ & $86.9 \pm 15.3$ \\
Lean MasSDEXA $^{2}$ & $\mathrm{~kg}$ & $47.1 \pm 7.1$ & $47.0 \pm 8.0$ \\
Fat MassDEXA $^{2}$ & $\mathrm{~kg}$ & $38.0 \pm 7.7$ & $37.8 \pm 7.8$ \\
Android Fat Mass $^{2}$ & $\mathrm{~kg}$ & $3.33 \pm 0.99$ & $3.48 \pm 1.04$ \\
Gynoid Fat Mass $^{2}$ & $\mathrm{~kg}$ & $6.36 \pm 1.45$ & $6.37 \pm 1.62$ \\
Android:Gynoid $^{2}$ & $\%$ & $52.1 \pm 0.11$ & $56.0 \pm 15.1$ \\
\% Body Fat $^{2}$ & $\%$ & $43.2 \pm 3.9$ & $43.3 \pm 3.0$ \\
\% Trunk Fat $^{2}$ & $\%$ & $44.2 \pm 5.3$ & $45.3 \pm 3.7$ \\
\hline 1. & $\%$ & &
\end{tabular}

$\overline{1-\text { All values are means } \pm \text { SD. Group mean differences were }}$ not detected by Student's t-tests $(\alpha=0.05)$. DEXA - dualenergy x-ray absorptiometry; DGAD - Dietary Guidelines for Americans diet; OM3I - omega-3 index; TAD - typical American diet; TG - triglycerides.

2- Reported values were derived from DEXA measurements 
medRxiv preprint doi: https://doi.org/10.1101/2021.09.22.21263899; this version posted September 23, 2021. The copyright holder for this preprint (which was not certified by peer review) is the author/funder, who has granted medRxiv a license to display the preprint in perpetuity. This article is a US Government work. It is not subject to copyright under 17 USC 105 and is also made available

Table 2: Aggregate meal composite fatty acid composition (mol\%) ${ }^{1}$

\begin{tabular}{cccc}
\hline Fatty Acid & TAD & DGAD & p-value \\
\hline C10:0 & $1.7 \pm 0.7$ & $0.90 \pm 0.40$ & 0.012 \\
C12:0 & $3.7 \pm 2.1$ & $0.63 \pm 0.43$ & 0.0013 \\
C14:0 & $5.6 \pm 1.7$ & $2.8 \pm 1.0$ & 0.0013 \\
C15:0 & $0.39 \pm 0.1$ & $0.22 \pm 0.07$ & 0.0018 \\
C16:0 & $24 \pm 3$ & $19 \pm 4$ & 0.0032 \\
C17:0 & $0.32 \pm 0.07$ & $0.18 \pm 0.06$ & 0.0007 \\
C18:0 & $8.5 \pm 0.9$ & $6.7 \pm 1.0$ & 0.0021 \\
C19:0 & $0.025 \pm 0.004$ & $0.023 \pm 0.005$ & 0.3 \\
C20:0 & $0.097 \pm 0.029$ & $0.11 \pm 0.02$ & 0.3 \\
C21:0 & $0.0035 \pm 0.0008$ & $0.0035 \pm 0.0007$ & 1 \\
C22:0 & $0.099 \pm 0.082$ & $0.13 \pm 0.06$ & 0.4 \\
C24:0 & $0.046 \pm 0.028$ & $0.064 \pm 0.024$ & 0.2 \\
C14:1n5 & $0.43 \pm 0.09$ & $0.18 \pm 0.09$ & 0.0001 \\
C16:1n7 & $1.3 \pm 0.5$ & $0.90 \pm 0.4$ & 0.07 \\
C18:1n9 & $31 \pm 4$ & $39 \pm 4$ & 0.0015 \\
C18:1n7 & $1.6 \pm 0.3$ & $2.0 \pm 0.4$ & 0.022 \\
C19:1n9 & $0.0088 \pm 0.0049$ & $0.0020 \pm 0.003$ & 0.005 \\
C20:1n9 & $0.072 \pm 0.030$ & $0.11 \pm 0.07$ & 0.2 \\
C18:2n6 & $18 \pm 5$ & $22 \pm 4$ & 0.05 \\
C18:3n6 & $0.024 \pm 0.011$ & $0.025 \pm 0.02$ & 0.9 \\
9c,11t-CLA & $0.085 \pm 0.017$ & $0.036 \pm 0.02$ & 0.0001 \\
C20:3n6 & $0.018 \pm 0.0054$ & $0.017 \pm 0.009$ & 0.6 \\
C20:4n6 & $0.087 \pm 0.036$ & $0.093 \pm 0.049$ & 0.8 \\
C22:4n6 & $0.019 \pm 0.0083$ & $0.020 \pm 0.010$ & 0.7 \\
C22:5n6 & $0.0061 \pm 0.0042$ & $0.013 \pm 0.010$ & 0.1 \\
C18:3n3 & $2.0 \pm 0.6$ & $3.6 \pm 1.2$ & 0.0046 \\
C18:4n3 & $0.014 \pm 0.027$ & $0.05 \pm 0.07$ & 0.2 \\
C20:3n3 & $0.0028 \pm 0.0017$ & $0.0076 \pm 0.0059$ & 0.046 \\
C20:4n3 & $0.0017 \pm 0.0007$ & $0.0080 \pm 0.0100$ & 0.09 \\
C20:5n3 & $0.0056 \pm 0.0083$ & $0.11 \pm 0.17$ & 0.1 \\
C22:5n3 & $0.045 \pm 0.012$ & $0.086 \pm 0.080$ & 0.2 \\
C22:6n3 & $0.021 \pm 0.006$ & $0.41 \pm 0.73$ & 0.2 \\
\hline SFA & $45 \pm 7$ & $30 \pm 6$ & 0.0003 \\
MUFA & $35 \pm 4$ & $43 \pm 4$ & 0.0022 \\
n-6 PUFA 3 PUFA & $18 \pm 5$ & $23 \pm 4$ & 0.05 \\
\hline A11 val & $2 \pm 1$ & $4 \pm 2$ & 0.0023 \\
\hline
\end{tabular}

1 - All values are means \pm SD. Group differences evaluated by Student's t-tests $(\alpha=0.05)$. DGAD - Dietary Guidelines for Americans diet; TAD - typical American diet; 
medRxiv preprint doi: https://doi.org/10.1101/2021.09.22.21263899; this version posted September 23, 2021. The copyright holder for this preprint (which was not certified by peer review) is the author/funder, who has granted medRxiv a license to display the preprint in perpetuity. This article is a US Government work. It is not subject to copyright under 17 USC 105 and is also made available for use under a CCO license.

Table 3: Average fatty acid intake (g/8-day rotation) ${ }^{1}$

\begin{tabular}{|c|c|c|c|}
\hline Fatty Acid & TAD & DGAD & p-value \\
\hline C10:0 & $18.2 \pm 1.8$ & $6.87 \pm 0.99$ & $<0.001$ \\
\hline $\mathrm{C} 12: 0$ & $45.3 \pm 4.4$ & $5.74 \pm 0.83$ & $<0.001$ \\
\hline $\mathrm{C} 14: 0$ & $78.3 \pm 7.8$ & $27.6 \pm 4$ & $<0.001$ \\
\hline $\mathrm{C} 15: 0$ & $5.89 \pm 0.59$ & $2.29 \pm 0.33$ & $<0.001$ \\
\hline C16:0 & $405 \pm 41$ & $208 \pm 30$ & $<0.001$ \\
\hline C17:0 & $5.69 \pm 0.57$ & $2.10 \pm 0.3$ & $<0.001$ \\
\hline C18:0 & $159 \pm 16$ & $83.6 \pm 12$ & $<0.001$ \\
\hline C19:0 & $0.488 \pm 0.049$ & $0.305 \pm 0.044$ & $<0.001$ \\
\hline $\mathrm{C} 20: 0$ & $2.09 \pm 0.21$ & $1.50 \pm 0.22$ & $<0.001$ \\
\hline $\mathrm{C} 21: 0$ & $0.0740 \pm 0.0074$ & $0.0500 \pm 0.0072$ & $<0.001$ \\
\hline $\mathrm{C} 22: 0$ & $2.42 \pm 0.24$ & $2.02 \pm 0.29$ & $<0.001$ \\
\hline $\mathrm{C} 24: 0$ & $1.18 \pm 0.12$ & $1.03 \pm 0.15$ & $<0.001$ \\
\hline $\mathrm{C} 14: \ln 5$ & $6.22 \pm 0.63$ & $1.82 \pm 0.26$ & $<0.001$ \\
\hline $\mathrm{C} 16: \ln 7$ & $22.9 \pm 2.3$ & $9.89 \pm 1.4$ & $<0.001$ \\
\hline C18:1n9 & $600 \pm 60$ & $494 \pm 71$ & $<0.001$ \\
\hline $\mathrm{C} 18: \ln 7$ & $29.3 \pm 2.9$ & $25.2 \pm 3.6$ & $<0.001$ \\
\hline $\mathrm{C} 19: \ln 9$ & $0.171 \pm 0.017$ & $0.0238 \pm 0.0034$ & $<0.001$ \\
\hline $\mathrm{C} 20: \ln 9$ & $1.54 \pm 0.15$ & $1.45 \pm 0.21$ & 0.1 \\
\hline C18:2n6 & $341 \pm 34$ & $279 \pm 41$ & $<0.001$ \\
\hline C18:3n6 & $0.453 \pm 0.046$ & $0.300 \pm 0.044$ & $<0.001$ \\
\hline 9c,11t-CLA & $1.55 \pm 0.16$ & $0.434 \pm 0.062$ & $<0.001$ \\
\hline $\mathrm{C} 20: 3 \mathrm{n} 6$ & $0.366 \pm 0.037$ & $0.213 \pm 0.030$ & $<0.001$ \\
\hline $\mathrm{C} 20: 4 \mathrm{n} 6$ & $1.77 \pm 0.18$ & $1.16 \pm 0.17$ & $<0.001$ \\
\hline $\mathrm{C} 22: 4 \mathrm{n} 6$ & $0.423 \pm 0.043$ & $0.280 \pm 0.041$ & $<0.001$ \\
\hline $\mathrm{C} 22: 5 \mathrm{n} 6$ & $0.140 \pm 0.014$ & $0.170 \pm 0.025$ & $<0.001$ \\
\hline $\mathrm{C} 18: 3 \mathrm{n} 3$ & $37.6 \pm 3.8$ & $45.9 \pm 6.7$ & $<0.001$ \\
\hline $\mathrm{C} 18: 4 \mathrm{n} 3$ & $0.243 \pm 0.026$ & $0.602 \pm 0.088$ & $<0.001$ \\
\hline $\mathrm{C} 20: 3 \mathrm{n} 3$ & $0.0612 \pm 0.0061$ & $0.104 \pm 0.015$ & $<0.001$ \\
\hline $\mathrm{C} 20: 4 \mathrm{n} 3$ & $0.0336 \pm 0.0034$ & $0.106 \pm 0.015$ & $<0.001$ \\
\hline $\mathrm{C} 20: 5 \mathrm{n} 3$ & $0.097 \pm 0.01$ & $1.36 \pm 0.2$ & $<0.001$ \\
\hline $\mathrm{C} 22: 5 \mathrm{n} 3$ & $0.973 \pm 0.099$ & $1.21 \pm 0.18$ & $<0.001$ \\
\hline $\mathrm{C} 22: 6 \mathrm{n} 3$ & $1.29 \pm 0.13$ & $16.6 \pm 2.4$ & $<0.001$ \\
\hline SFA & $724 \pm 73$ & $341 \pm 49$ & $<0.001$ \\
\hline MUFA & $660 \pm 66$ & $532 \pm 77$ & $<0.001$ \\
\hline n-6 PUFA & $345 \pm 35$ & $282 \pm 41$ & $<0.001$ \\
\hline n-3 PUFA & $40.3 \pm 4.1$ & $65.9 \pm 9.6$ & $<0.001$ \\
\hline
\end{tabular}

1 - All values are means \pm SD. Group differences evaluated by Student's t-tests $(\alpha=0.05)$. DGAD - Dietary Guidelines for Americans diet; TAD - typical American diet 
medRxiv preprint doi: https://doi.org/10.1101/2021.09.22.21263899; this version posted September 23, 2021. The copyright holder for this preprint (which was not certified by peer review) is the author/funder, who has granted medRxiv a license to display the preprint in perpetuity. This article is a US Government work. It is not subject to copyright under 17 USC 105 and is also made available for use under a CCO license.

Table 4: Amounts of foods providing >0.3g/d of dietary ALA, EPA and DHA ${ }^{1}$

\begin{tabular}{|c|c|c|c|c|}
\hline \multirow{2}{*}{$\begin{array}{c}\text { Menu } \\
\text { Day }\end{array}$} & \multicolumn{2}{|l|}{ TAD } & \multicolumn{2}{|l|}{ DGAD } \\
\hline & Food Items & $\mathrm{g} / \mathrm{d}$ & Food Items & $\mathrm{g} / \mathrm{d}$ \\
\hline 1 & None & & $\begin{array}{r}\text { Roasted Potatoes } \\
\text { Baked Salmon }\left(\mathbf{1 . 7 g / d ) ^ { 2 }}\right. \\
\text { Cinnamon Chex } \\
\end{array}$ & $\begin{array}{r}150 \\
80 \\
30\end{array}$ \\
\hline 2 & $\begin{array}{r}\text { Pizza Crust } \\
\text { Mashed Potatoes } \\
\text { Ranch Dressing }\end{array}$ & $\begin{array}{l}86 \\
75 \\
30\end{array}$ & $\begin{array}{r}\text { Roasted Potatoes } \\
\text { Stuffing } \\
\text { Cinnamon Chex } \\
\text { pizza crust } \\
\text { Ranch Dressing }\end{array}$ & $\begin{array}{r}150 \\
150 \\
30 \\
86 \\
30\end{array}$ \\
\hline 3 & None & & $\begin{array}{r}\text { Roasted Potatoes } \\
\text { Goddess Dressing }\end{array}$ & $\begin{array}{c}150 \\
\mathrm{~g} \\
30 \mathrm{~g}\end{array}$ \\
\hline 4 & Ranch Dressing & 30 & $\begin{array}{r}\text { Salsa Ranch Dressing } \\
\text { Tomato Basil Sauce } \\
\text { Tortilla Chips }\end{array}$ & $\begin{array}{c}30 \\
150 \\
30 \\
\end{array}$ \\
\hline 5 & Breakfast Muffins & 65 & $\begin{array}{r}\text { Cinnamon Apples } \\
\text { Baked Salmon }\left(\mathbf{1 . 7 g / d ) ^ { 2 }}\right. \\
\text { Salsa Ranch Dressing } \\
\text { Walnuts }\end{array}$ & $\begin{array}{c}150 \\
80 \\
30 \\
5\end{array}$ \\
\hline 6 & $\begin{array}{r}\text { Corn-cheddar biscuit } \\
\text { Caesar Salad dressing } \\
\text { Granola Bars }\end{array}$ & $\begin{array}{c}130 \\
30 \\
37\end{array}$ & $\begin{array}{r}\text { Roasted Potatoes } \\
\text { Corn-cheddar biscuit } \\
\text { Ranch Dressing } \\
\text { Walnuts }\end{array}$ & $\begin{array}{c}150 \\
65 \\
30 \\
5\end{array}$ \\
\hline 7 & $\begin{array}{r}\text { Seafood Salad }(0.3 \mathrm{~g} / \mathrm{d})^{2} \\
\text { Mashed Pinto Beans } \\
\text { Popcorn Chicken } \\
\text { Corn Chips } \\
\text { Club Crackers } \\
\text { Oreo Cookies }\end{array}$ & $\begin{array}{c}100 \\
60 \\
35 \\
30 \\
28 \\
20\end{array}$ & $\begin{array}{r}\text { Cinnamon Apples } \\
\text { Canned Albacore Tuna }(0.7 \mathrm{~g} / \boldsymbol{d})^{2} \\
\text { Thousand Island Dressing } \\
\text { Walnuts }\end{array}$ & $\begin{array}{c}150 \\
80 \\
30 \\
5\end{array}$ \\
\hline 8 & $\begin{array}{r}\text { Pancakes } \\
\text { Breaded Chicken Patty }\end{array}$ & $\begin{array}{c}150 \\
85\end{array}$ & None & \\
\hline
\end{tabular}

1 - DGAD - Dietary Guidelines for American's diet; TAD - typical American diet

2 - Data in parentheses indicate EPA and DHA content estimated by the Nutrition Data System for Research (v 2014), University of Minnesota Nutrition Coordinating Center (http://www.ncc.umn.edu/products/). 
Table 5: RBC fatty acid mole percent composition ${ }^{1}$

\begin{tabular}{|c|c|c|c|c|c|c|}
\hline \multirow[b]{2}{*}{ Fatty Acid } & \multicolumn{3}{|c|}{ TAD $(n=20)$} & \multicolumn{3}{|c|}{ DGAD $(\mathrm{n}=22)$} \\
\hline & Wk 0 & Wk 2 & Wk 8 & Wk 0 & Wk 2 & Wk 8 \\
\hline C14:0 & $1.28 \pm 0.73^{\mathrm{AB}}$ & $1.05 \pm 1.00^{\mathrm{B}}$ & $1.55 \pm 1.20^{\mathrm{A}}$ & $1.29 \pm 0.93$ & $1.11 \pm 0.49$ & $0.993 \pm 0.66$ \\
\hline C15:0 & $0.387 \pm 0.300$ & $0.371 \pm 0.074$ & $0.288 \pm 0.54$ & $0.346 \pm 0.130$ & $0.319 \pm 0.082$ & $0.306 \pm 0.39$ \\
\hline $\mathrm{C} 16: 0$ & $29.5 \pm 3.8$ & $30.1 \pm 3.3$ & $29.8 \pm 1.0$ & $28.7 \pm 4.1$ & $30.0 \pm 3.1$ & $29.7 \pm 3.3$ \\
\hline $\mathrm{C} 17: 0$ & $0.401 \pm 0.11$ & $0.362 \pm 0.12$ & $0.449 \pm 0.34$ & $0.430 \pm 0.110$ & $0.356 \pm 0.095$ & $0.404 \pm 0.15$ \\
\hline C18:0 & $24.2 \pm 4.2$ & $23.6 \pm 4.1$ & $23.7 \pm 6.3$ & $26.0 \pm 5.4$ & $24.9 \pm 4.6$ & $24.3 \pm 5.2$ \\
\hline $\mathrm{C} 18: \ln 9$ & $10.9 \pm 1.3$ & $10.7 \pm 1.1$ & $10.6 \pm 5.5$ & $10.8 \pm 1.7$ & $10.7 \pm 1.6$ & $10.9 \pm 1.7$ \\
\hline $\mathrm{C} 18: \ln 7$ & $2.07 \pm 0.38$ & $2.03 \pm 0.26$ & $1.92 \pm 0.23$ & $1.95 \pm 0.65$ & $2.02 \pm 0.44$ & $1.98 \pm 0.43$ \\
\hline $\mathrm{C} 18: 2 \mathrm{n} 6$ & $6.52 \pm 0.94$ & $6.42 \pm 0.90$ & $6.36 \pm 6.2$ & $6.31 \pm 0.92$ & $5.94 \pm 0.73$ & $5.91 \pm 0.95$ \\
\hline $\mathrm{C} 20: 3 \mathrm{n} 6$ & $1.25 \pm 0.24$ & $1.28 \pm 0.35$ & $1.33 \pm 1.6$ & $1.39 \pm 0.46$ & $1.42 \pm 0.43$ & $1.37 \pm 0.19$ \\
\hline $\mathrm{C} 20: 4 \mathrm{n} 6$ & $9.55 \pm 1.4$ & $9.93 \pm 1.50$ & $10.1 \pm 2.2$ & $9.21 \pm 1.3$ & $9.29 \pm 1.4$ & $9.22 \pm 1.4$ \\
\hline $\mathrm{C} 22: 4 \mathrm{n} 6$ & $4.06 \pm 0.73$ & $4.11 \pm 0.83$ & $4.28 \pm 0.26$ & $4.22 \pm 0.88$ & $4.20 \pm 0.85$ & $4.00 \pm 0.88$ \\
\hline $\mathrm{C} 22: 5 \mathrm{n} 6$ & $0.834 \pm 0.32$ & $0.877 \pm 0.28$ & $0.841 \pm 0.23$ & $0.899 \pm 0.27^{\mathrm{ab}}$ & $0.945 \pm 0.26^{\mathrm{a}}$ & $0.727 \pm 0.3^{b}$ \\
\hline $\mathrm{C} 20: 5 \mathrm{n} 3$ & $0.430 \pm 0.130^{\mathrm{A}}$ & $0.381 \pm 0.082^{\mathrm{AB}}$ & $0.345 \pm 0.64^{\mathrm{B}}$ & $0.383 \pm 0.15^{b}$ & $0.422 \pm 0.13^{b}$ & $0.493 \pm 0.18^{\mathrm{a}}$ \\
\hline $\mathrm{C} 22: 5 \mathrm{n} 3$ & $3.14 \pm 0.73$ & $3.20 \pm 0.84$ & $3.02 \pm 1.20$ & $2.90 \pm 0.75$ & $2.93 \pm 0.59$ & $2.89 \pm 0.82$ \\
\hline $\mathrm{C} 22: 6 \mathrm{n} 3$ & $5.47 \pm 1.1$ & $5.57 \pm 0.69$ & $5.45 \pm 0.46$ & $5.24 \pm 0.89^{b}$ & $5.47 \pm 1.3^{b}$ & $6.86 \pm 1.3^{\mathrm{a}}$ \\
\hline$\Sigma$ SFA & $55.8 \pm 3.5$ & $55.5 \pm 3.6$ & $55.8 \pm 9.5$ & $56.7 \pm 4.1$ & $56.7 \pm 4.1$ & $55.7 \pm 3.9$ \\
\hline$\Sigma$ MUFA & $12.9 \pm 1.6$ & $12.7 \pm 1.3$ & $12.5 \pm 1.6$ & $12.7 \pm 2.2$ & $12.7 \pm 2$ & $12.8 \pm 2$ \\
\hline इn-6 PUFA & $22.2 \pm 2.3$ & $22.6 \pm 2.6$ & $22.9 \pm 1.2$ & $22.0 \pm 2.6$ & $21.8 \pm 2.2$ & $21.2 \pm 2.6$ \\
\hline$\Sigma$ n-3 PUFA & $9.04 \pm 1.4$ & $9.15 \pm 0.79$ & $8.82 \pm 1.8$ & $8.52 \pm 1.3^{b}$ & $8.83 \pm 1.8^{b}$ & $10.3 \pm 1.6^{\mathrm{a}}$ \\
\hline OM3-I & $5.90 \pm 1.4$ & $5.95 \pm 1.2$ & $5.8 \pm 0.72$ & $5.63 \pm 1.3^{b}$ & $5.89 \pm 0.95^{b}$ & $7.36 \pm 1.4^{\mathrm{a}}$ \\
\hline
\end{tabular}

1- All values are means \pm SD. Mean differences for each fatty acid between times within diet groups were assessed by ANOVAs controlling for participant as a random effect and a least squares mean difference Tukey HSD post-hoc tests. For each fatty acid residue, values within diet groups with different superscripts are different at $\alpha=0.05$. TAD - typical American diet; DGAD - Dietary Guidelines for Americans diet; OM3I - omega-3 index 
medRxiv preprint doi: https://doi.org/10.1101/2021.09.22.21263899; this version posted September 23, 2021. The copyright holder for this preprint (which was not certified by peer review) is the author/funder, who has granted medRxiv a license to display the preprint in perpetuity.

This article is a US Government work. It is not subject to copyright under 17 USC 105 and is also made available for use under a CCO license.

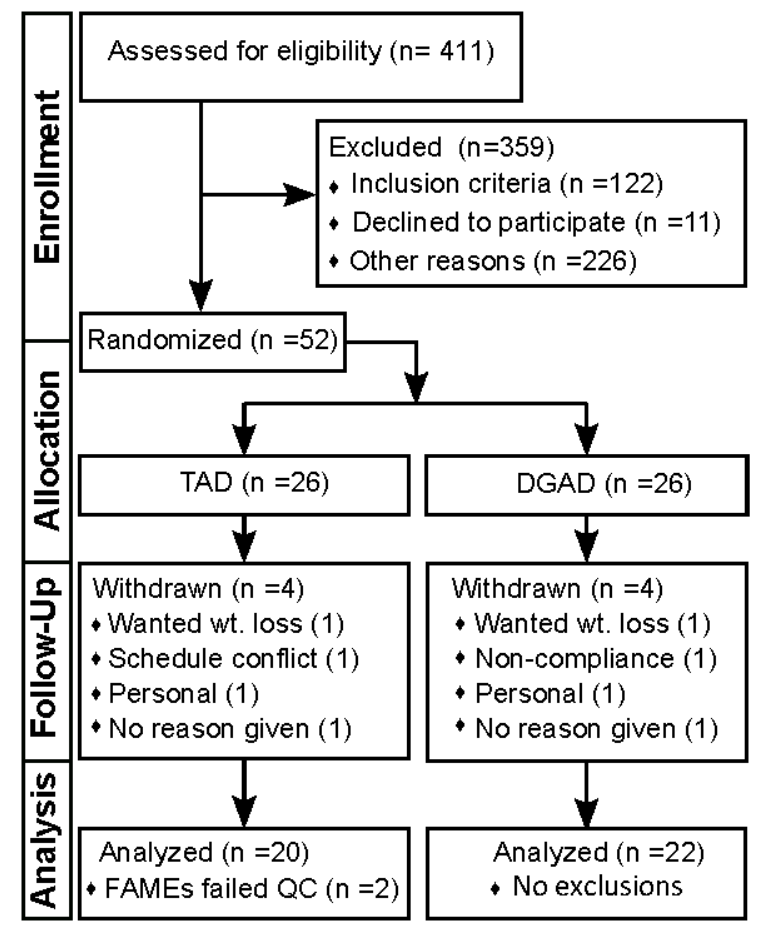

Figure 1: Study flow diagram documenting participant enrollement, allocation, follow-up

and analysis. This diagram conforms the Consolidated Standards of Reporting Trials (i.e. CONSORT). TAD - typical American diet; DGAD - Dietary Guidelines for American's diet; FAMEs - red blood cell fatty acid analysis; QC - quality control criterion. 


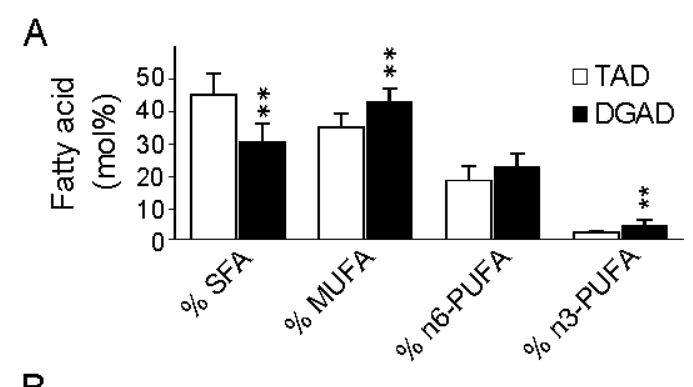

B

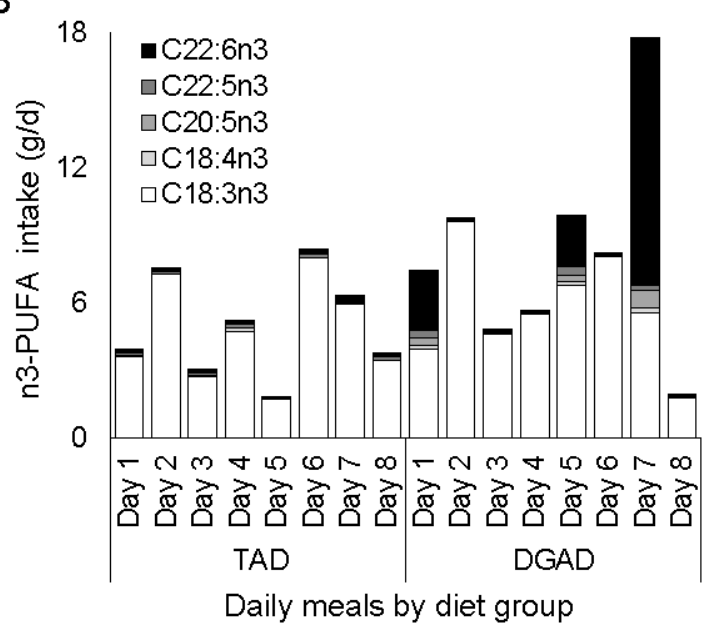

Figure 2: Fatty acid composition of TAD and DGAD menus. A) Aggregate meal composite fatty acid composition differences between the typical American diet (TAD) and Dietary Guidelines for American's diet (DGAD) menus. Mean composition differences between meal plans are indicated at $\mathrm{p}<0.001(* *)$. B) Omega-3 PUFA fatty acid composition in individual meals of the 8-day rotating TAD and DGAD plans. Individual fatty acid residues are displayed if occurring at $>0.1 \mathrm{~mol} \%$ of any meal. Fatty acid mol\% composition was determined in duplicate from a single set of meal composities by GC-MS analysis of fatty acid methyl esters. 
medRxiv preprint doi: https://doi.org/10.1101/2021.09.22.21263899; this version posted September 23, 2021. The copyright holder for this preprint (which was not certified by peer review) is the author/funder, who has granted medRxiv a license to display the preprint in perpetuity. This article is a US Government work. It is not subject to copyright under 17 USC 105 and is also made available for use under a CCO license.

A

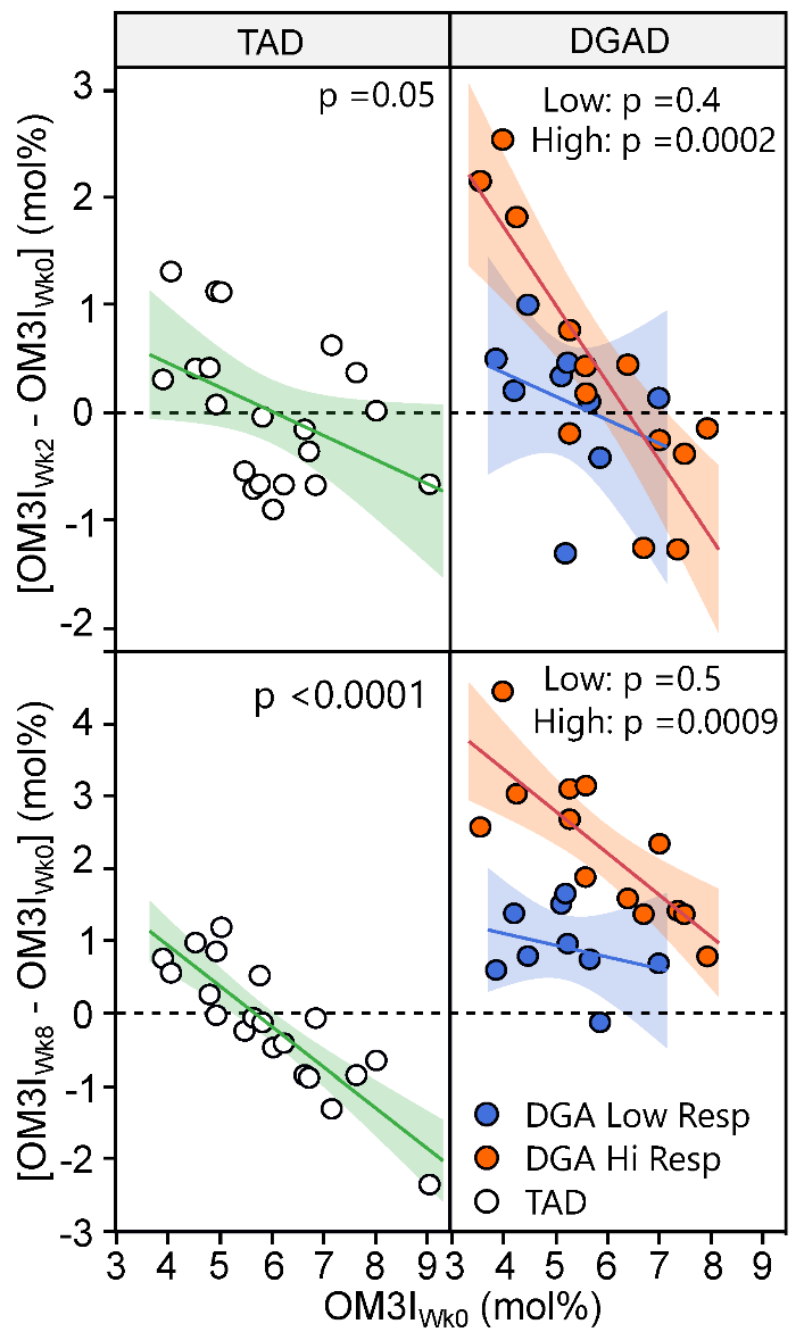

B

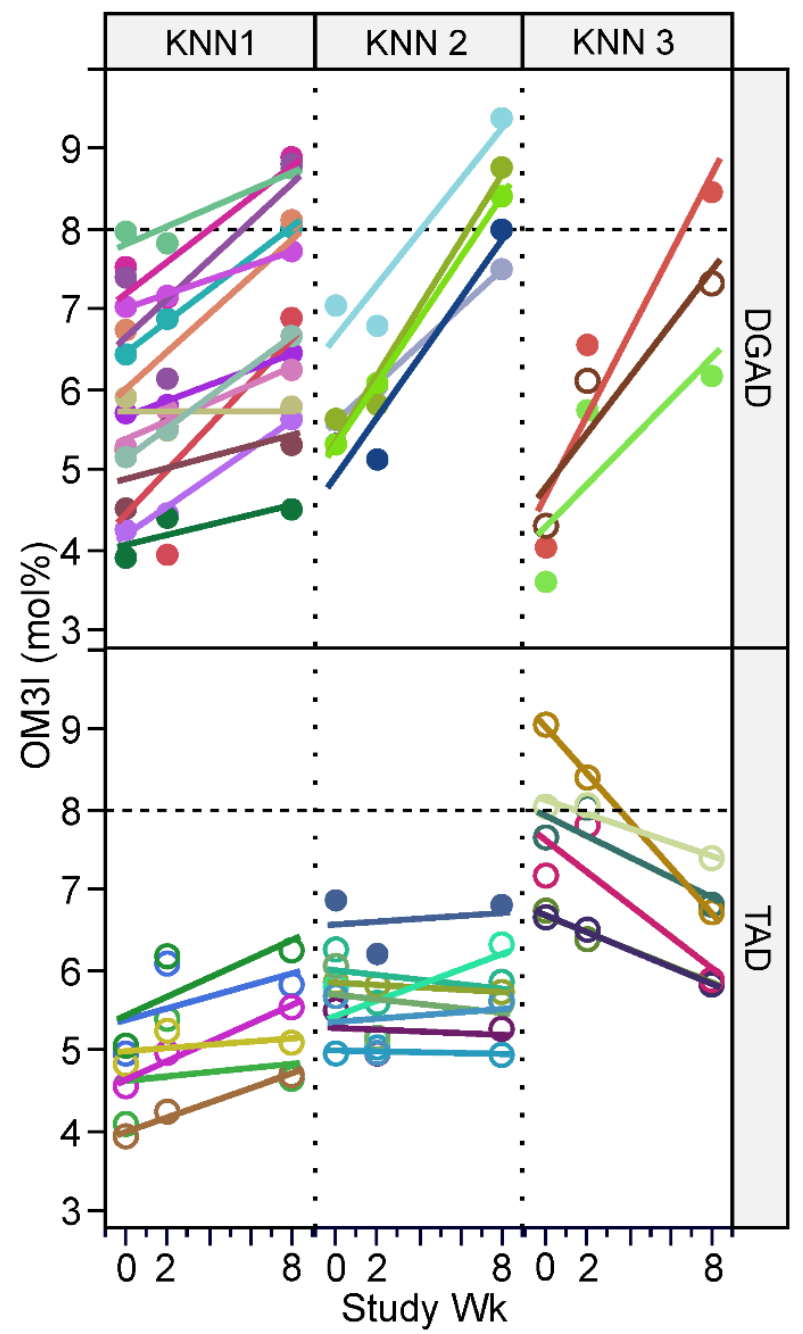

Figure 3: Omega-3 index response variance by diet group and time. A) Participants within the typical American diet (TAD) and Dietary Guidelines for American's diet (DGAD) groups were clustered according to their baseline adjusted omega-3 index (OM3I) fold change at $8 \mathrm{wks}$ by hierarchical cluster analysis and projected on both $2 \mathrm{wk}$ (top) and $8 \mathrm{wk}$ (bottom) data. Identified DGAD subgroups are described as Low (blue) and High (orange) responding groups The correlations between basal status and magnitude of change were significant in the High, but not Low response groups. B) Participants within the TAD and DGAD groups were clustered based on their OM3I rate of change and basal status, by K-means clustering, with each diet group being segregated into 3 groups of participants with different responses. In the TAD group $(\mathrm{n}=20)$, the OM3I stabilized at $5.8 \pm 0.7$ across all groups, while participants in the DGAD group $(\mathrm{n}=22)$ generally increased after 8 wks of feeding. 
medRxiv preprint doi: https://doi.org/10.1101/2021.09.22.21263899; this version posted September 23, 2021. The copyright holder for this preprint (which was not certified by peer review) is the author/funder, who has granted medRxiv a license to display the preprint in perpetuity. This article is a US Government work. It is not subject to copyright under 17 USC 105 and is also made available for use under a CCO license.

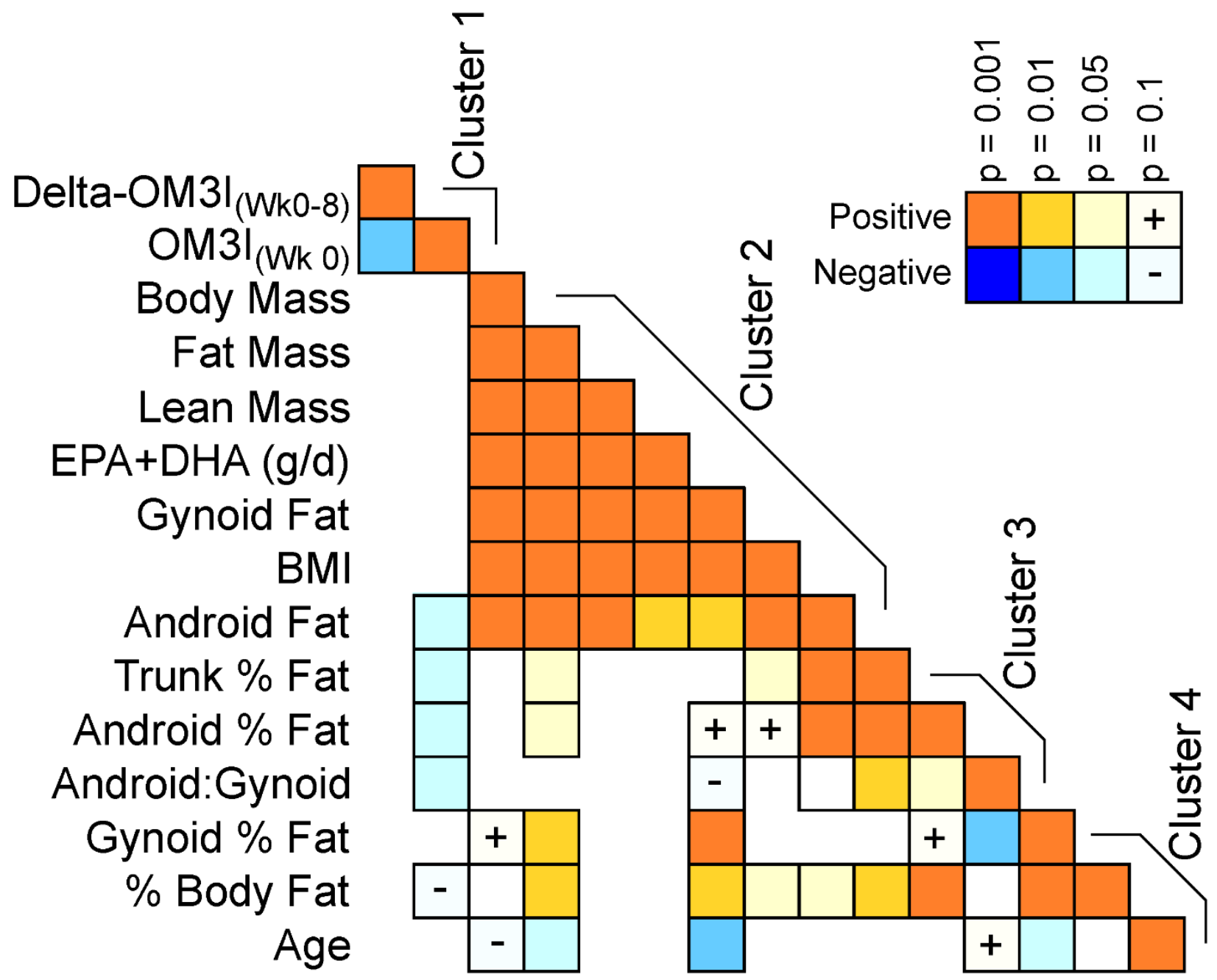

Figure 4: Pearson's correaltion heatmap of the DGAD-group 8wk change in omega-3 status, basal omega-3 statis and DEXA-dependent body composition measures. Correlation statistics are calculated on normally transformed data, with positive (orange) and negative (blue) correlation strength indicated by color intensity. Variables were clustered in Jmp v16 using implementation of the SAS Varclus algorithm. Delta-OM3 $\mathrm{I}_{(\mathrm{Wk} 0-8)}-8 \mathrm{wk}$ change in OM3I; $\mathrm{EPA}+\mathrm{DHA}$ - estimated daily intake; OM3I $(\mathrm{Wk} 0)$ - basal omega 3 index. 
medRxiv preprint doi: https://doi.org/10.1101/2021.09.22.21263899; this version posted September 23, 2021. The copyright holder for this

preprint (which was not certified by peer review) is the author/funder, who has granted medRxiv a license to display the preprint in perpetuity. This article is a US Government work. It is not subject to copyright under 17 USC 105 and is also made available

\section{References}

1. Roger, V.L., et al., Heart disease and stroke statistics--2011 update: a report from the American Heart Association. Circulation, 2011. 123(4): p. e18-e209.

2. Khan, S.U., et al., Effect of omega-3 fatty acids on cardiovascular outcomes: A systematic review and meta-analysis. EClinicalMedicine, 2021.

3. Jung, U.J., et al., n-3 Fatty acids and cardiovascular disease: mechanisms underlying beneficial effects. Am J Clin Nutr, 2008. 87(6): p. 2003S-9S.

4. Jump, D.B., C.M. Depner, and S. Tripathy, Omega-3 fatty acid supplementation and cardiovascular disease. Journal of Lipid Research, 2012. 53(12): p. 2525-2545.

5. Mozaffarian, D. and J.H. Wu, Omega-3 fatty acids and cardiovascular disease: effects on risk factors, molecular pathways, and clinical events. J Am Coll Cardiol, 2011. 58(20): p. 2047-67.

6. Mori, T.A., Marine OMEGA-3 fatty acids in the prevention of cardiovascular disease. Fitoterapia, 2017. 123: p. 51-58.

7. Handelsman, Y. and M.D. Shapiro, Triglycerides, Atherosclerosis, and Cardiovascular Outcome Studies: Focus on Omega-3 Fatty Acids. Endocr Pract, 2017. 23(1): p. 100-112.

8. McKenney, J.M. and D. Sica, Role of prescription omega-3 fatty acids in the treatment of hypertriglyceridemia. Pharmacotherapy, 2007. 27(5): p. 715-28.

9. Skulas-Ray, A.C., et al., Omega-3 Fatty Acids for the Management of Hypertriglyceridemia: A Science Advisory From the American Heart Association. Circulation, 2019. 140(12): p. e673-e691.

10. Backes, J., et al., The clinical relevance of omega-3 fatty acids in the management of hypertriglyceridemia. Lipids Health Dis, 2016. 15(1): p. 118.

11. Harris, W.S., L. Del Gobbo, and N.L. Tintle, The Omega-3 Index and relative risk for coronary heart disease mortality: Estimation from 10 cohort studies. Atherosclerosis, 2017. 262: p. 51-54.

12. Flock, M.R., et al., Determinants of erythrocyte omega-3 fatty acid content in response to fish oil supplementation: a dose-response randomized controlled trial. J Am Heart Assoc, 2013. 2(6): p. e000513.

13. Sarter, B., et al., Blood docosahexaenoic acid and eicosapentaenoic acid in vegans: Associations with age and gender and effects of an algal-derived omega-3 fatty acid supplement. Clin Nutr, 2015. 34(2): p. 212-8.

14. Dougherty, R.M., et al., Lipid and phospholipid fatty acid composition of plasma, red blood cells, and platelets and how they are affected by dietary lipids: a study of normal subjects from Italy, Finland, and the USA. Am J Clin Nutr, 1987. 45(2): p. 443-55.

15. Franco, R.S., Measurement of red cell lifespan and aging. Transfus Med Hemother, 2012. 39(5): p. 302-7.

16. Harris, W.S. and C. Von Schacky, The Omega-3 Index: a new risk factor for death from coronary heart disease? Prev Med, 2004. 39(1): p. 212-20.

17. Keenan, A.H., et al., Basal omega-3 fatty acid status affects fatty acid and oxylipin responses to high-dose n3-HUFA in healthy volunteers. J Lipid Res, 2012. 53(8): p. 1662-9.

18. von Schacky, C., Omega-3 index and cardiovascular health. Nutrients, 2014. 6(2): p. 799-814. 
medRxiv preprint doi: https://doi.org/10.1101/2021.09.22.21263899; this version posted September 23, 2021. The copyright holder for this

preprint (which was not certified by peer review) is the author/funder, who has granted medRxiv a license to display the preprint in perpetuity. This article is a US Government work. It is not subject to copyright under 17 USC 105 and is also made available for use under a CCO license.

19. Zhang, Z., et al., Dietary Intakes of EPA and DHA Omega-3 Fatty Acids among US Childbearing-Age and Pregnant Women: An Analysis of NHANES 2001-2014. Nutrients, 2018. 10(4).

20. Fazelian, S., et al., Effect of omega-3 fatty acids supplementation on cardio-metabolic and oxidative stress parameters in patients with chronic kidney disease: a systematic review and meta-analysis. BMC Nephrol, 2021. 22(1): p. 160.

21. Walker, R.E., et al., Predicting the effects of supplemental EPA and DHA on the omega-3 index. Am J Clin Nutr, 2019. 110(4): p. 1034-1040.

22. Zibaeenezhad, M.J., et al., Comparison of the effect of omega-3 supplements and fresh fish on lipid profile: a randomized, open-labeled trial. Nutr Diabetes, 2017. 7(12): p. 1.

23. Stanton, A.V., et al., Omega-3 index and blood pressure responses to eating foods naturally enriched with omega-3 polyunsaturated fatty acids: a randomized controlled trial. Sci Rep, 2020. 10(1): p. 15444.

24. Papanikolaou, Y., et al., U.S. adults are not meeting recommended levels for fish and omega-3 fatty acid intake: results of an analysis using observational data from NHANES 2003-2008. Nutr J, 2014. 13: p. 31.

25. Arterburn, L.M., E.B. Hall, and H. Oken, Distribution, interconversion, and dose response of $n-3$ fatty acids in humans. Am J Clin Nutr, 2006. 83(6 Suppl): p. 1467S$1476 \mathrm{~S}$.

26. Goyens, P.L., et al., Conversion of alpha-linolenic acid in humans is influenced by the absolute amounts of alpha-linolenic acid and linoleic acid in the diet and not by their ratio. Am J Clin Nutr, 2006. 84(1): p. 44-53.

27. Brenna, J.T., et al., alpha-Linolenic acid supplementation and conversion to n-3 longchain polyunsaturated fatty acids in humans. Prostaglandins Leukot Essent Fatty Acids, 2009. 80(2-3): p. 85-91.

28. Baker, E.J., et al., Metabolism and functional effects of plant-derived omega-3 fatty acids in humans. Prog Lipid Res, 2016. 64: p. 30-56.

29. Harnack, K., G. Andersen, and V. Somoza, Quantitation of alpha-linolenic acid elongation to eicosapentaenoic and docosahexaenoic acid as affected by the ratio of n6/n3 fatty acids. Nutr Metab (Lond), 2009. 6: p. 8.

30. Plissonneau, C., et al., High-Intensity Interval Training and alpha-Linolenic Acid Supplementation Improve DHA Conversion and Increase the Abundance of Gut MucosaAssociated Oscillospira Bacteria. Nutrients, 2021. 13(3).

31. Minihane, A.M., Impact of Genotype on EPA and DHA Status and Responsiveness to Increased Intakes. Nutrients, 2016. 8(3): p. 123.

32. Krishnan, S., et al., A randomized controlled-feeding trial based on the Dietary Guidelines for Americans on cardiometabolic health indexes. Am J Clin Nutr, 2018. 108(2): p. 266-278.

33. Krishnan, S., et al., Challenges in Designing and Delivering Diets and Assessing Adherence: A Randomized Controlled Trial Evaluating the 2010 Dietary Guidelines for Americans. Curr Dev Nutr, 2020. 4(3): p. nzaa022.

34. Katz, A., et al., Quantitative insulin sensitivity check index: a simple, accurate method for assessing insulin sensitivity in humans. J Clin Endocrinol Metab, 2000. 85(7): p. 2402-10.

35. Grapov, D., et al., Type 2 diabetes associated changes in the plasma non-esterified fatty acids, oxylipins and endocannabinoids. PLoS One, 2012. 7(11): p. e48852. 
medRxiv preprint doi: https://doi.org/10.1101/2021.09.22.21263899; this version posted September 23, 2021. The copyright holder for this

preprint (which was not certified by peer review) is the author/funder, who has granted medRxiv a license to display the preprint in perpetuity. This article is a US Government work. It is not subject to copyright under 17 USC 105 and is also made available for use under a CCO license.

36. Tepaamorndech, S., et al., Zinc transporter 7 deficiency affects lipid synthesis in adipocytes by inhibiting insulin-dependent Akt activation and glucose uptake. FEBS J, 2016. 283(2): p. 378-94.

37. Smedes, F., Determination of total lipid using non-chlorinated solvents. Analyst, 1999. 124: p. 1711-1718.

38. Lemaitre, R.N., et al., Red blood cell membrane alpha-linolenic acid and the risk of sudden cardiac arrest. Metabolism, 2009. 58(4): p. 534-40.

39. Burns-Whitmore, B., et al., Alpha-Linolenic and Linoleic Fatty Acids in the Vegan Diet: Do They Require Dietary Reference Intake/Adequate Intake Special Consideration? Nutrients, 2019. 11(10).

40. Garneau, V., et al., Omega-3 fatty acids status in human subjects estimated using a food frequency questionnaire and plasma phospholipids levels. Nutr J, 2012. 11: p. 46.

41. Ritz, P.P., et al., Dietary and Biological Assessment of the Omega-3 Status of Collegiate Athletes: A Cross-Sectional Analysis. PLoS One, 2020. 15(4): p. e0228834.

42. Zhang, A.C. and L.E. Downie, Preliminary Validation of a Food Frequency Questionnaire to Assess Long-Chain Omega-3 Fatty Acid Intake in Eye Care Practice. Nutrients, 2019. 11(4).

43. Block, R.C., W.S. Harris, and J.V. Pottala, Determinants of Blood Cell Omega-3 Fatty Acid Content. Open Biomark J, 2008. 1: p. 1-6.

44. Muka, T., et al., Dietary fat composition, total body fat and regional body fat distribution in two Caucasian populations of middle-aged and older adult women. Clin Nutr, 2017. 36(5): p. 1411-1419.

45. Alferink, L.J.M., et al., Nonalcoholic Fatty Liver Disease in The Rotterdam Study: About Muscle Mass, Sarcopenia, Fat Mass, and Fat Distribution. J Bone Miner Res, 2019. 34(7): p. 1254-1263.

46. Bouchi, R., et al., Gender difference in the impact of gynoid and android fat masses on the progression of hepatic steatosis in Japanese patients with type 2 diabetes. BMC Obes, 2017. 4: p. 27.

47. Kang, S.M., et al., Android fat depot is more closely associated with metabolic syndrome than abdominal visceral fat in elderly people. PLoS One, 2011. 6(11): p. e27694.

48. $\quad$ Sari, C.I., et al., Android Fat Deposition and Its Association With Cardiovascular Risk Factors in Overweight Young Males. Front Physiol, 2019. 10: p. 1162.

49. Albert, B.B., et al., Higher omega-3 index is associated with increased insulin sensitivity and more favourable metabolic profile in middle-aged overweight men. Sci Rep, 2014. 4: p. 6697.

50. Connor, W.E., Effects of omega-3 fatty acids in hypertriglyceridemic states. Semin Thromb Hemost, 1988. 14(3): p. 271-84.

51. Skulas-Ray, A.C., et al., Dose-response effects of omega-3 fatty acids on triglycerides, inflammation, and endothelial function in healthy persons with moderate hypertriglyceridemia. Am J Clin Nutr, 2011. 93(2): p. 243-52. 